
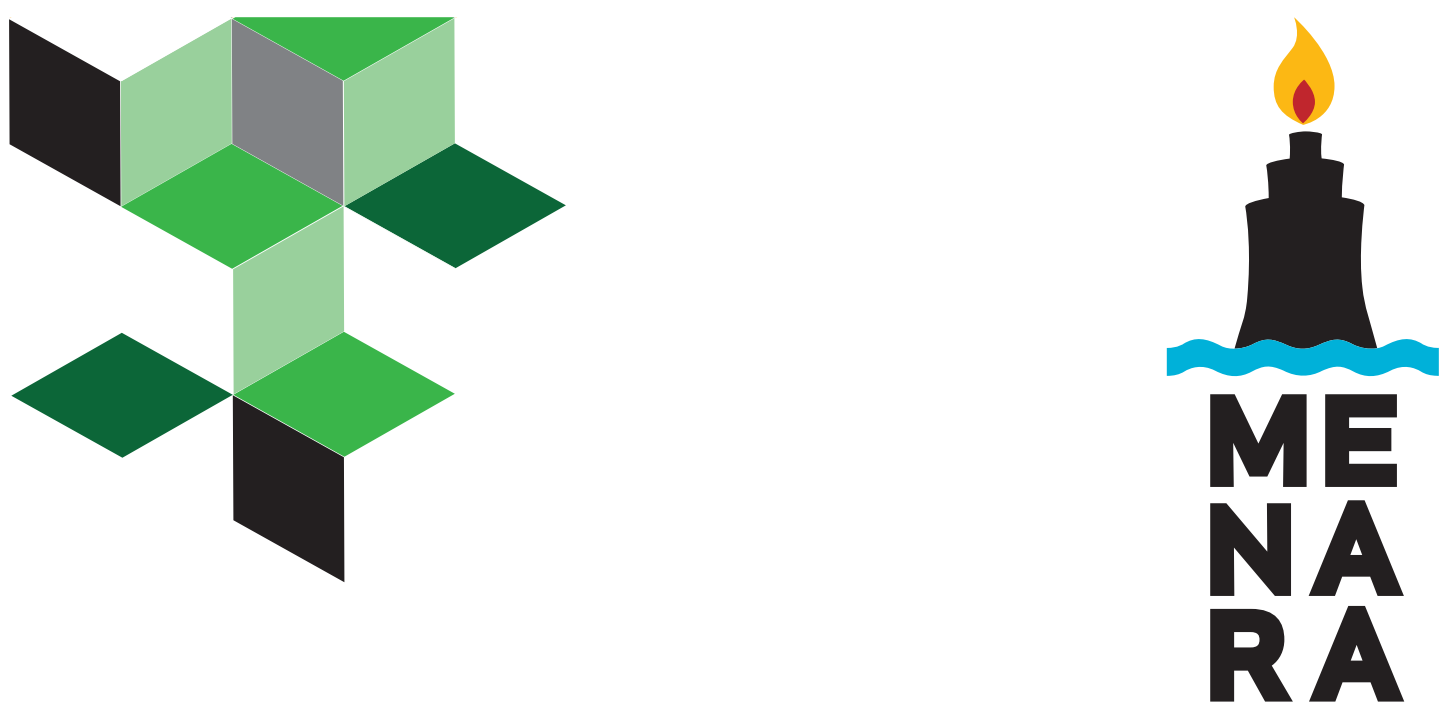

MENARA Final Reports

No. 1, February 2019

INTERREGNUM:

THE REGIONAL ORDER IN THE

MIDDLE EAST AND NORTH AFRICA

AFTER 2011

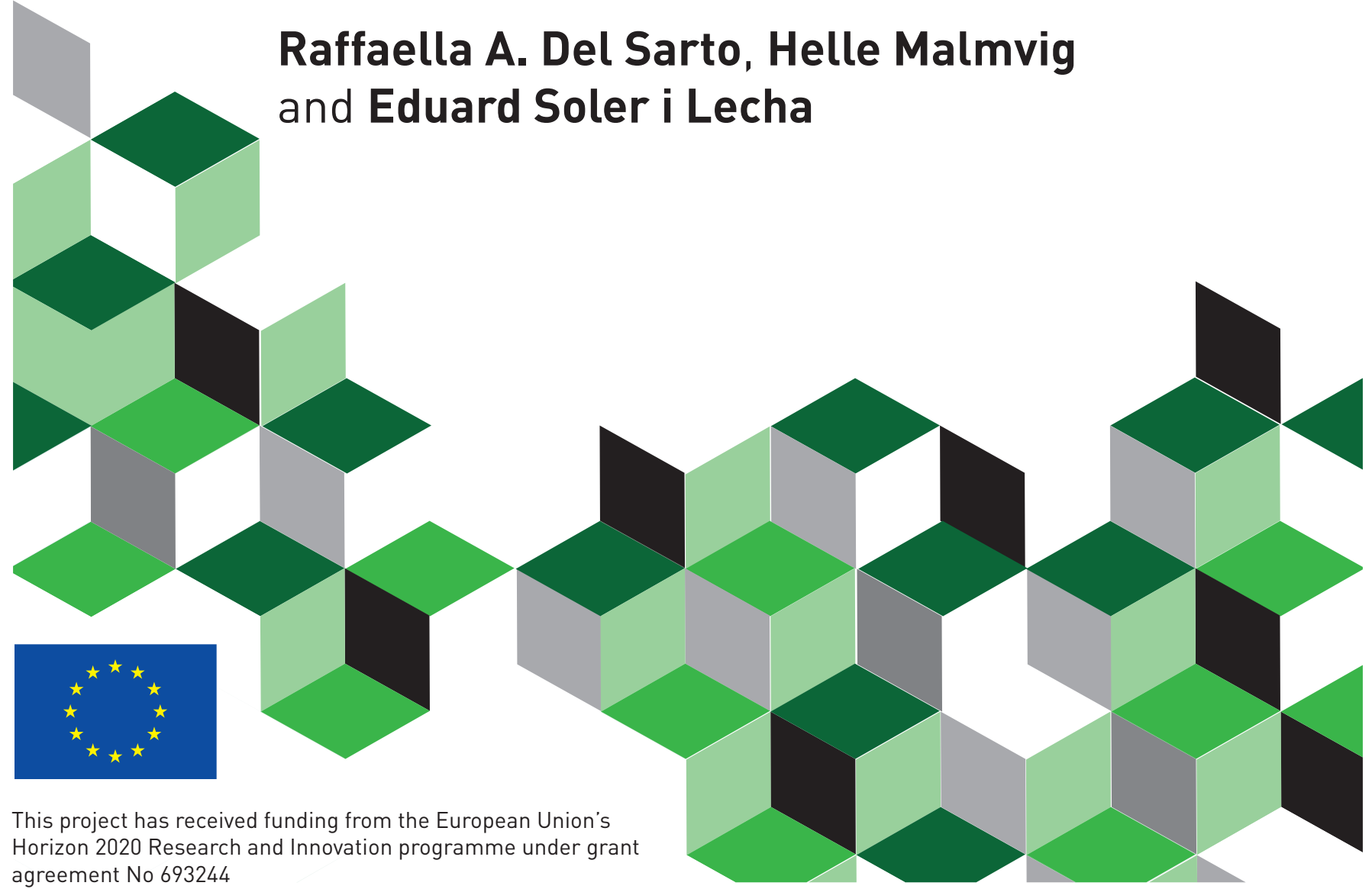




\section{TABLE OF CONTENTS}

$\begin{array}{ll}\text { Executive Summary } & \text { p. } 3\end{array}$

$\begin{array}{ll}\text { Introduction } & 5\end{array}$

1. Regional Order and Change: Conceptual Underpinnings 7

2. The Domestic-Regional Nexus: The Weakening of States, Heightened Regime 12 Insecurities and Sectarian Securitization

2.1 The Weakening of States and the Growing Role of Non-State Actors 12

2.1.1 Regional Implications $\quad 15$

2.2 Regime Insecurities and Authoritarian Resilience 16

$\begin{array}{lll}2.3 & \text { Ethno-sectarian Securitization } & 17\end{array}$

3. Regional Dynamics: Polarity, Patterns of Amity and Enmity, Alliances and 19 Geopolitical Shifts

3.1 Patterns of Multipolarity: Beyond the Saudi-Iranian Confrontation 19

3.2 Patterns of Amity and Enmity: Overlapping and Multi-layered Cleavages 21

3.2.1 The Arab-Israeli Conflict and the Norm of Arab Unity 22

3.2.2 Sectarian Securitization at a Regional Scale 25

3.2.3 Change versus Status Quo 27

3.3 Patterns of Cooperation: Liquid Alliances and the Mirage of Regionalism 29

3.4 Shifting Centres of Gravity: The Gulf and Africa 33

4. International Permeation and the Degree of Regional Autonomy 35

4.1 Independent Foreign Policies and Space of Manoeuvre 36

4.2 Tail-wags-the-dog Dynamics: Drawing Powers in and the Internalization of Security 38 Perceptions

Summary and Conclusions $\quad 42$

$\begin{array}{ll}\text { References } & 46\end{array}$ 


\section{EXECUTIVE SUMMARY}

This report contends that the Middle East regional order since 2011 has changed in several ways. This is evidenced by the decline in US power, the rise of sectarianism, the growing influence of non-state actors, the return of Arab state permeability, intensified rivalry between Iran and Saudi Arabia, the emergence of regional players such as Turkey, Qatar and the United Arab Emirates, and the fluidity of alliances. However, these and other changes constitute a change within order, rather than of order. Below are listed some of the main take-away points from the report. Each theme is developed in detail in the report, allowing the reader to go into more depth in the separate sections.

- Middle East scholars and observers have been rather generous in the way they have repeatedly identified changes in the MENA's regional order over the decades, with analyses usually focusing on variations in the relative power of states, changing patterns of amity and enmity, and the influence of external actors. Ignoring important changes at the intersection between domestic and regional politics, such a perspective fails to detect significant shifts within the regional order that may transform the region in the medium and long term.

- Increased numbers of armed non-state actors - transnational ethnic and sectarian groups, rebels, tribes, terrorist organizations, foreign militias and mercenaries - are challenging states' claims to monopoly of violence and territorial control. Yet the sovereign state system and territorial boundaries are more resilient than widely assumed.

- The obsession of regimes with remaining in power has further blurred the boundary between the domestic and the regional, as perceived threats to regime survival are balanced by often erratic foreign policies, interventions and ever-shifting alliances.

- Sectarian entrepreneurs and political leaders have enhanced their power and deflected demands for change by manipulating fears of political exclusion, claiming to protect certain sections of the population from others, or using sectarianism to discredit their political opponents and regional rivals.

- Explanations of regional politics that are based on notions of Sunni-Shia antagonism are overly simplistic and may even lead to dangerous policy prescriptions, such as breaking up states along ethno-sectarian lines, fortifying autocratic governments' repressive practices or reinforcing Orientalist understandings of the Middle East as "all about religion", and conflicts therefore endemic to the region.

- There is not just a single defining division in this region. Patterns of amity and enmity are the result of the overlap of three main fault lines. These divide between (1) those that are ready to normalize relations with Israel and those that oppose it; (2) those that confront each other along identity lines and by doing so insufflate life into regional forms of sectarianism; and (3) those that are in favour of political change versus those who defend the status quo. The latter cleavage is also linked to the question of supporting the presence of the Muslim Brotherhood as a regional actor versus trying to eradicate it. 
- Anti-Zionism has ceased to be a major defining feature of Arab politics. Instead, shared hostility towards Iran and its allies has been forging a new rapprochement between Israel and a number of Arab states. However, the norm of Arab solidarity and the Palestinian cause still resonate very much with Arab publics, pointing (once more) to the ever-growing disconnect between Arab regimes and their populations.

- Since 2011, one-off events have been changing the perception of what or who represents a threat and this is why alliances limited to single issues proliferate. Such liquid alliances are not durable and constantly adapt to different landscapes. The eruption of simultaneous and intersecting regional conflicts has increased the sense of unreliability in allies and prompted more assertive and often aggressive attitudes towards both rivals and friends.

- Since 2011, we have witnessed shifts in the centres of gravity of the MENA region. The Gulf has replaced the Mashreq/Levant as the main geopolitical centre, while the Maghreb, but also other parts of the Middle East, have been pivoting towards the African continent.

- The American unipolar moment is long gone. The 2003 US invasion of Iraq and its catastrophic aftermath, the US retreat from the region and Russia's willingness to fill the power vacuum in Syria, in addition to China flexing its economic muscles across the region, have created a new reality, where the USA is only one among many global powers.

- States that continue to present themselves as US allies are also very much willing to strengthen links with Moscow and Beijing. Egypt, Saudi Arabia, Turkey and even Israel are able to play external powers off against each other, thereby obtaining concessions and leverage. At times, Middle Eastern governments have even succeeded in manoeuvring global powers to do what they otherwise might not have done. Often, such tail-wags-the-dog dynamics work in rather subtle ways, as global powers internalize or uncritically take over the security perceptions of regional allies.

- After the Arab uprisings, the MENA region entered a period in which the existing order is increasingly challenged while an alternative is still to be framed. 


\title{
INTERREGNUM: THE REGIONAL ORDER IN THE MIDDLE EAST AND NORTH AFRICA AFTER 2011
}

\author{
Raffaella A. Del Sarto, Helle Malmvig and Eduard Soler i Lecha'
}

The crisis consists precisely in the fact that the old is dying and the new cannot be born: in this interregnum, morbid phenomena of the most varied kind come to pass.

Antonio Gramsci ${ }^{2}$

\section{INTRODUCTION}

The Arab uprisings of 2011 and their aftermath triggered a new iteration of the old debate on whether the Middle East and North Africa (MENA) had been transformed in a fundamental way or whether the region had changed only gradually at best. This debate has accompanied every major event in the region, prompting Valbjørn and Bank (2012: 4) to recall Fred Halliday's astute remark that "there are two predictable and nearly always mistaken responses to any great international upheaval: one is to say that everything has changed; the other is to say that nothing has changed". The initially perhaps predominant view was that the Arab uprisings could herald a profound and irreversible transformation of the region, which could eventually lead to the emergence of a new regional order (Rózsa 2013, Legrenzi 2015, Dazi-Héni 2016, Dalay 2017). Yet, the old order proved to be more resilient than expected as the hopes of a democratic Middle East faded away, the self-declared Islamic State began losing territory and the predictions of an imminent end of the "Sykes-Picot borders" revealed themselves to be a myth (e.g. Lynch 2016, 2018; Del Sarto 2017a; Del Sarto and Okyay 2017, Fawcett 2017).

A more useful approach, which is relevant to scholars and practitioners alike, is to analytically and empirically assess the question of what kind of change the region has been witnessing. What is new and what is not? In this spirit, the purpose of this report is to assess the prevailing trends and dynamics that have been shaping the regional order in the MENA region following the 2011 Arab uprisings. It will seek to examine the quality, extent and intensity of these changes, as well as their implications. Based on the findings, it will also try to answer the question of whether we have been witnessing a change of the regional order in MENA or rather changes within the (old) order.

The notion of regional order is, of course, far from being self-evident. In everyday parlance, the Middle East is often referred to as a "disorderly region". Paul Salem (2014: 6) remarked, for instance, that the "Middle East is one of the few regions without any semblance of a regional security, economic, or political order to contain conflict and manage its intra-regional affairs". Yet,

1 Raffaella A. Del Sarto is Associate Professor of Middle East Studies at the Johns Hopkins University School of Advanced International Studies, SAIS Europe, and Part-time Professor at the Robert Schuman Centre, European University Institute (EUI). Helle Malmvig is Senior Researcher at the Danish Institute for International Studies (DIIS). Eduard Soler i Lecha is Senior Researcher at the Barcelona Centre for International Affairs (CIDOB) and Scientific Coordinator of the MENARA project.

2 Notebook 3 (1930), para. 34. See Gramsci (1996: 32-33). 
and as originally developed by the English School of International Relations, "regional order" as an analytical concept is not to be conflated with "orderly", let alone peaceful, relations among actors belonging to a region. Rather, regional order signifies varied forms of interactions, negotiations, common assumptions or even shared norms and institutions among the actors of a given region. Thus, and as explained in more detail below, our concept of regional order draws on an English School understanding of this notion as well as on the concept of regional security complexes, as developed by Buzan and Wæver (2003: 44). Our approach to, and investigation of, the regional order in the MENA region thus applies an International Relations lens to understand the dynamics marking the region post-2011. In this way, it contributes to scholarly attempts to bridge the persisting gap between the academic disciplines of International Relations and Middle East area studies (see, e.g., Halliday 2005: ch. 1, Teti 2007, Valbjørn 2003, Buzan and Gonzalez-Pelaez 2009; POMEPS 2015).

This report is one of the final outcomes of the MENARA project, a three-year collaborative research project bringing together fourteen research centres from the European Union, Turkey, the Maghreb, the Mashreq and the Gulf. The analysis is based on numerous fact-finding missions, in most countries of the region but also in Europe, Russia, China and the USA, in addition to 269 face-to-face interviews with a diverse pool of actors. These include pro-government and opposition politicians, public officials, members of security forces, officials in international and regional organizations, members of the private sector, intellectuals, experts and civil society activists. Those inputs were then contrasted with the assessment of seventy-one experts participating in a Delphi Survey, ${ }^{3}$ three focus group discussions in Beirut, Rabat and Brussels, and two stakeholder meetings in Rome and Istanbul.

The report is structured as follows: it starts with a discussion of the theoretical underpinnings of our analysis by focusing in particular on the key concepts of regional order and change (section 1). In this context, the report elaborates on the crucial distinction between change of orderversus changes within the existing regional order. The subsequent empirical analysis of the changes that have been marking the MENA region post-Arab uprisings is divided into three main parts. The report first assesses significant changes at the intersection between domestic and regional politics, including the weakening of states, increased regime insecurities and sectarian securitization (section 2). It then shifts the focus of attention to predominantly regional dynamics, which are, however, also shaped by domestic and international developments (section 3). In this section, the question of polarity of the regional system, and changing patterns of amity and enmity, cooperation and alliances are analysed, together with major geopolitical shifts. The final part of the empirical discussion (section 4) focuses on global dynamics that have been prompting or influencing changes at the regional level, such as variations in the degree of permeability of the regional system and the extent of regional autonomy. In its conclusions, the report will return to the question of whether since the Arab uprisings, the MENA region has been witnessing a change of the regional order or if the observed transformations are indications of changes within the

3 Delphi is a methodology often used for long-term prospection and thinking. It is suited to coping with a high degree of uncertainty and to addressing highly complex issues. The MENARA Project Delphi survey was conducted with 71 experts that previously agreed to participate in it. They were asked to assess developments for both 2025 and 2050 and, when relevant, to differentiate impacts in different territories of this region. Due to the advanced technical nature of this Real-Time Delphi Survey, the participants were able to see the responses of all the other experts (anonymously) at all times, and they were able to change and adjust their answers as often as they liked or found it to be necessary. 
regional order in MENA. Maintaining that the latter is the case, we will lay out the main implications of our findings.

\section{REGIONAL ORDER AND CHANGE: CONCEPTUAL UNDERPINNINGS}

As a starting point, we may broadly sketch the main features of the regional order in the MENA region since the emergence of the modern state system and until 2011 as a state-centric one with a strong authoritarian and military component. Multipolarity, together with overlapping cleavages, shifting alliances and a high incidence of conflicts and wars characterized the region during these decades. While the Mashreq/Levant was the geopolitical centre of the regional order in MENA, the region had an Arab core, which led some authors to refer to an Arab regional order and its failures (Sayigh 1991, Barnett 1995). This core coexisted with three non-Arab regional powers (Iran, Turkey and Israel), which are part of region-wide securitization dynamics. The Arab-Israeli conflict was a major structuring feature of regional politics, and the regional order was also marked by a number of formal pan-Arab institutions, which were nevertheless often ignored or bypassed by its members.

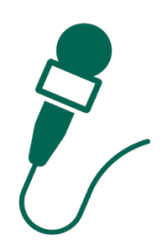

Interview with an expert from the MENA region: The key actors in this region are pretty much the same for the last 20-30 years, with a shift in weights. All new actors are tools in the hands of regional and global powers such as Saudi Arabia, Iran, United States, Russia or Israel.

The period after 1979 witnessed the growing role of non-Arab regional powers in MENA, combined with a progressive decline in the status and power of Egypt within the Arab state system. Moreover, the MENA region became more consistently and more thoroughly "ensnarled in great power politics than any other part of the non-Western world" (Brown 1984: 3), while, on the other hand, no outside power has ever been able to attain hegemonic control or successfully order the region (Brown 1984: 270). It is also relevant that the very existence of MENA, or the Middle East, as an actual region has been disputed (e.g. Bilgin 2004, 2015), revealing that there has been a lack of consensus on the definition of the region, its members and its boundaries. Finally, MENA has been a composite region, including relatively autonomous sub-regions such as the Maghreb, the Mashreq/Levant and the Gulf (see Figure 1), whose security dynamics are, however, interlinked (Buzan and Wæver 2003).

Assessing the regional order in MENA post-Arab uprisings, and evaluating possible changes and developments, is a far more challenging undertaking than this initial overview would suggest. To begin with, the definition of a region has remained difficult indeed, as extensively discussed in the concept and methodology paper of the MENARA project (Malmvig et al. 2016). Following the definition that a region is a set of "geographical units made up of territorially based political entities, tied together by high and persistent levels of political, economic, security-based and/or cultural interaction among them [...] and/or by a shared sense of belonging" (Malmvig et al. 2016: 
33), we posit that MENA qualifies as a region, made up of the states of the so-called Arab core as well as the three non-Arab countries Turkey, Iran and Israel.

Figure 1 | The MENA and its sub-regions

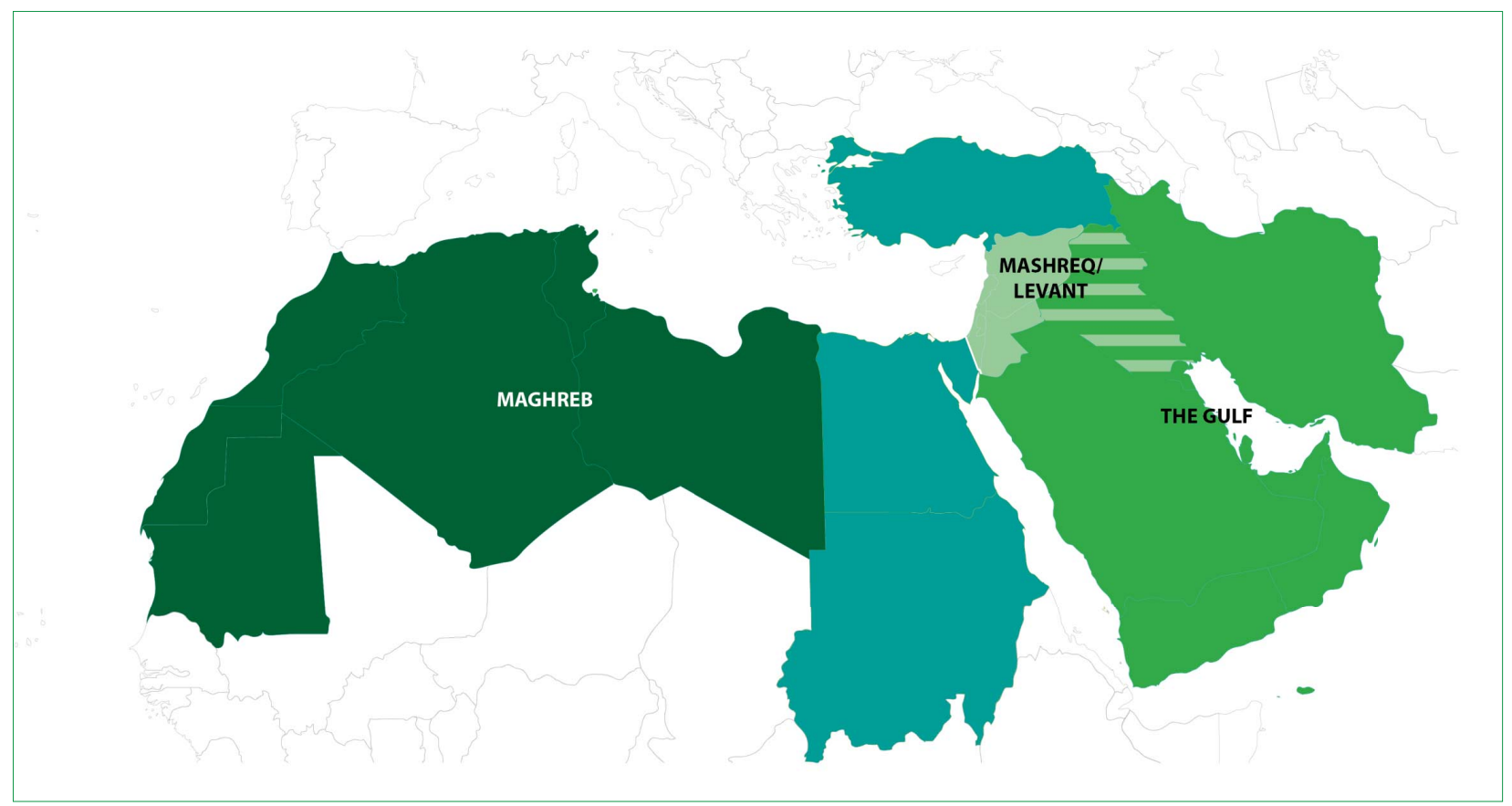

The second major difficulty lies in the definition of the concept of regional order, which is far from being obvious. As Michael Leifer (2005: 98) remarked with regard to South East Asia, regional order is "a high-sounding aspiration which is difficult to define with any precision". For him, in general terms, regional order means "the existence of a stable structure of regional inter-governmental relationships informed by common assumptions about the bases of inter-state conduct". The difficulties of defining a regional order have been discussed extensively in the MENARA concept paper as well (Malmvig et al. 2016: 38-41). As a working definition, the MENARA project initially used a modified version of the definition of international - and consequently of regional - order as suggested by Alagappa (2003: 39). Regional order was thus defined as a formal or informal arrangement that sustains rule-governed interactions among different units within a system in their pursuit of individual and collective goals.

The empirical investigations of different aspects of the regional order in the MENA region conducted in the framework of the MENARA project during the last three years (April 2016-March 2019) point to the need to simultaneously broaden and fine-tune this characterization. In conceptual terms, we may best approach the amorphous idea of regional order by recalling the definition of regional security complexes provided by Buzan and Wæver (2003: 44), namely that of a "set of units whose major processes of securitisation, desecuritisation, or both are so interlinked that their security problems cannot reasonably be analysed or resolved apart from one another". While the domestic and regional features of the main units (or actors) in the regional system are important, the nature of their security interdependence and the type of securitization and desecuritization processes 
are thus central to the definition of a regional order. But similarly relevant are patterns of amity and enmity, and, more broadly, the normative environment of regional politics. Expanding on Barnett's analysis of the Arab regional order (Barnett 1998), symbolic battles and (re)negotiations over meaning in the regional arena - which usually have very real material implications - are key characteristics of regional orders as well. Of great importance are also durable or consistent practices and institutions, which structure relations between actors within the region. However, norms and intersubjective beliefs of what constitutes a legitimate actor, and what the parameters of rightful state action are, have been contested in the MENA region ever since the emergence of the modern state system. The most prominent examples are the contested legitimacy of the State of Israel and the challenges to the legitimacy and sovereignty of Arab states emanating from pan-Arabism and pan-Islamism. Similarly, the constant interference by international and regional actors in the domestic affairs of MENA states is testament to the contestation of the norms of sovereignty and legitimacy of the main actors within the regional system. Perhaps paradoxically, the specific battles over the meanings of these norms have been an important marker of the regional order in MENA, and they have structured relations between the actors in the system.

Based on these considerations, and in light of the research findings of the MENARA project so far, an assessment of the regional order needs to take a number of key elements into account. The following features shape and define interactions among the actors within the regional system and form the basis of their expectations:

- The domestic features of the main actors in the regional system. These are usually states, but may also comprise non-state actors. Key characteristics include the institutional strength of these actors, their domestic sovereignty and legitimacy, and the type of state-society relations.

- The distribution of material and ideological power within the region.

- The patterns of amity and enmity, which may be fluid, along with formal and informal alliances and major fault lines of conflict.

- The normative environment and the ideological underpinnings of politics, including shared beliefs and practices, such as pan-Arabism, pan-Islamism and sectarianism.

- Formal and non-formal institutions, including regional organizations but also institutions in the sociological sense, such as sovereignty.

- The degree and features of external influence and permeability. ${ }^{4}$

Third, the question arises of whether there is a hierarchy of the defining elements of a regional order and, if so, what this hierarchy looks like. In accordance with the main characteristics of the regional order identified above, a useful starting point is the distinction between (1) the domestic and regional features of the main players of the regional system, (2) the type of interaction between these actors and (3) the international/external permeation and permeability of the regional system. This model stipulates an intrinsic interconnectedness between different levels of analysis, forcing us to consider the impact of domestic dynamics on regional politics, the predominantly regional dimension of interaction between states that may be shaped by domestic and international politics, and the influence of global dynamics on regional politics (and vice versa). The question of which

4 We consciously use the terms "permeation" and "permeability" instead of the term "[international] penetration" (of the Middle East), which is often used in the literature: first, these terms depart from an Orientalist and gendered perception of the Middle East; second, they account for the fact that not only actors but also broader developments (such as globalization) may impact on (or permeate) the region; and third, they allow for a consideration of bi-directionality. On the concept of permeability, see for example Salloukh and Brynen (2004). 
level of analysis is more pertinent at a particular moment in time does not have a fixed answer: it is an empirical question. However, different types of ordering principles, such as constitutive structures, shared and durable practices and institutions, and much looser and issue-specific agreements may be present in all three dimensions, albeit to varying degrees and with a different relevance. Following Reus-Smit's reflections on hierarchy within international society (Reus-Smit 1997), we may posit that there is a hierarchy of ordering principles at different levels of analysis, with constitutional structures being at the top of this hierarchy, followed by fundamental and durable institutions and practices that define legitimate behaviour in the system. Looser and less durable agreements in specific issue-areas would thus be at the bottom of this hierarchy lalso Buzan and Gonzalez-Pelaez 2009: 92-116, Quero and Soler 2017). ${ }^{5}$

Fourth, there has been much debate in the literature on the question of what counts as a change of MENA's regional order. Considering the literature, Middle East scholars would by and large agree that the regional order has changed several times since the emergence of the modern state system, with the 1950s and 1960s marking the first period of a distinctive regional order. The creation of Israel, the struggle for independence, the quest for regional hegemony, the rise of Nasser, the "Arab Cold War" (Kerr 1971), the 1956 Suez war and the end of British hegemony, and in general, "oligarchic multipolarity" marked the regional order in this period (Hinnebusch 2003: ch. 6). After 1967, the regional order of MENA underwent an important transformation, characterized by the Arab-Israeli wars and the so-called Arab triangle (Egypt, Saudi Arabia and Syria). ${ }^{6}$ This period also witnessed the end of pan-Arabism (Ajami 1998) and the rise of Islamism, while the Arab-Israeli conflict increasingly overlapped with the Cold War. Moreover, state consolidation but also processes of fragmentation within the Arab system (Kerr and Yassin 1982, Corm 1988) were important features of the regional order in this time span. After 1979, the regional order changed again, this time triggered by Egypt's separate peace deal with Israel, the revolution in Iran, the Iran-Iraq war that established a new line of conflict, and the growing influence of the USA in the region.

The end of the Cold War and the advent of the 1991 Gulf War, which allegedly led to a period of Pax Americana in the Middle East, prompted much debate in the literature (Hudson 1992). Did these events indeed lead to a new order? Or was Pax Americana merely stabilizing the old order?? This debate in fact raised (once more) the questions of what a structural change is and whether stability and stabilization are essential features of new - or rather of old? - orders in the Middle East. Importantly, while the previous changes of order were primarily triggered by developments

5 With reference to international society, Reus-Smit (1997) suggested that the "constitutional structure" of international society is at the top of the hierarchy, followed by "fundamental institutions" and "international regimes". According to this author, the constitutional structure consists of a coherent set of intersubjective beliefs and norms. This structure defines what constitutes a legitimate actor, entitled to all the rights and privileges of statehood; and it defines the basic parameters of rightful state action. Primary institutions are shared and durable social practices that define legitimate behaviour in the system (such as sovereignty, territoriality, war and nationalism). International regimes enact basic institutional practices among states in specific issue-areas (Reus-Smit 1997: 556-558).

6 The "Arab triangle" consisted of Egypt as the strongest Arab state, Saudi Arabia as the richest and Syria as the most anti-Zionist and most pan-Arab state.

7 Hudson (1992) identifies four scenarios for the impact of the Pax Americana on the Middle East. The first scenario mentions a new order which is more stable; the second, a new order but less stable; the third, no new order and the region remains fairly stable; and the fourth, no new order but a potent level of instability in the region. 
that were endogenous to the region, the debate on the regional order in the Middle East after the end of the Cold War focused mainly on the degree of US influence. There is much less academic debate on the regional order that emerged after the 2003 US invasion of Iraq (Quero and Dessì 2019).

Until recently, Middle East scholarship has been rather generous in stipulating what a change of order is. The elements that were considered as central for assessing change included variations in the relative (material and ideological) strength and power of the main "units" in the system (usually states) and the emergence of new ones, together with changing patterns of amity and enmity defining the region - such as alliances, wars and some occasional peace agreements. According to the dominant view in the literature, the influence of actors that are external to the region, such as the USA during and after the Cold War, is equally central. Normative underpinnings of politics and durable practices and institutions, such as Pan-Arabism with its pro-Palestinian and antiZionist positions, are also considered in the literature, although they are perhaps not deemed as essential in defining a change of the regional order.

A look at the MENA region today reveals a number of striking features and developments. As discussed in more detail below, these include, inter alia, heightened regime insecurities, sectarianism, authoritarian resilience, altered dynamics of polarity, the growing role of land partly antagonism between) regional powers, shifting patterns of amity and enmity, and a greater external permeation of the region. What are the broader implications of these changes? And to what extent are these features really new? Did the Arab uprisings and their aftermath trigger some of these developments or did the uprisings accelerate trends that had started much earlier? Similarly significant is the question of whether these developments constitute a structural change of MENA's regional order.

Based on our discussion of the defining features of regional order so far, how can we conceptualize a change of regional order in the MENA region? What would such scenarios look like? A number of developments, and the combination of some of these, could qualify as a change of the regional order in MENA. As it remains difficult to separate the traditional levels of analysis due to their interconnectedness, we may first consider the intersection between state-society relations and the regional level. We may posit that a change of order would occur if there were major alterations in the main constitutional principles and durable practices at this intersection, such as the autonomy of states and the monopoly of violence. Thus, anything signifying the erosion or collapse of the organizing principles of sovereignty and territoriality, the break-up of states, the emergence of sectarian states and the ensuing redrawing of international borders would count as such scenarios. But we would also identify a change of order if the prevailing form of government in the MENA region was transformed. The emergence of a predominantly liberal and democratically governed region would therefore replace authoritarianism and ethno-religious nationalism as two prevalent and durable practices marking the region at present. A predominance of accountable, liberal and "outward-looking" governments may well also shift the region towards greater integration and cooperation (Solingen 2007 and 2015). The emergence of supra-national structures and the devolution of central state authority to the regional level would count as significant changes as well. 
At the regional level, we may reasonably speak of a change of order if the region developed into a unipolar or bipolar system. Similarly, scenarios in which only one cleavage or line of conflict came to dominate the region, or alternatively in which there was no conflict at all, would constitute significant changes of order. Continuing this line of thinking, and considering the traditionally strong structuring power of the Arab-Israeli conflict, a scenario in which the Palestine question was no longer a mobilizing factor for Arab populations, and/or in which Israel was accepted as a "normal" and integral part of the region, would count as a major change. Similarly, stable, meaningful and formalized alliances, leading to the emergence of regional collective security organizations, would represent a change of the regional order; and the same could be said if, conversely, there were no longer any alliances at all. A fundamentally altered composition of the region and a different collective understanding of who is part of it and who is not would also signify such a change.

At the intersection between the regional and the global order, a significant shift in the degree of international permeation and meddling would certainly be considered as a change of MENA's regional order. Such scenarios include the complete cessation of foreign interference or, alternatively, a situation in which one or several non-Western hegemons would dominate the region.

From this vantage point, the major transformations that we have been witnessing in the MENA region and their implications merit more detailed analysis. They will be the subject of our discussion in the following sections.

\section{THE DOMESTIC-REGIONAL NEXUS: THE WEAKENING OF STATES, HEIGHTENED REGIME INSECURITIES AND SECTARIAN SECURITIZATION}

\subsection{THE WEAKENING OF STATES AND THE GROWING ROLE OF NON-STATE ACTORS}

Before 2011, Middle Eastern states were relatively strong and centralized in terms of their administrative and penetrative capacities (Mann 1988, Yapp 1991, Owen 2000, Collombier et al. 2018). MENA states were not, to use a controversial term, failed states (see, e.g., Call 2010, Bøås and Jennings 2007). Although regimes lacked popular legitimacy, relied heavily on the repressive security apparatus and had often captured the very institutions of the state - blurring the boundary between regime and state - they predominantly functioned and governed as states. The state apparatus could reach even remote areas of its territory and was able, although to varying degrees, to deliver collective services and goods, including security by claiming a monopoly on the means of violence and coercion. These states were, in short, relatively strong, but not very legitimate. Then, as the uprisings turned into armed conflicts and proxy wars unfolded in several Arab states, we see a weakening of states in Libya, Syria, Yemen, Iraq and to some extent in Egypt (see also Salloukh 2017: 660, Lynch 2018, Boserup and Colombo 2017: 2). Here wars and extreme foreign meddling have eroded state capacities and enhanced the permeability of the Arab state in a territorial sovereign sense (on permeability Salloukh and Brynen 2004). 


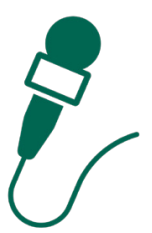

Interview with a businessman in Libya: Armed actors are playing a major role, especially the extremist and criminal ones. They profit from the weakness and incapacity of the state. External powers are using them to promote their own interests.

A wide array of armed non-state actors - transnational ethnic and sectarian militias, rebels, tribes, terrorist organizations and foreign militias and mercenaries - are challenging states' claims to monopoly over the means of violence and territorial control. Armed groups who are in opposition to incumbent governments are waging wars against the formal security forces of the state; they are capturing and controlling territories and in Libya, Yemen and Syria, and opposition forces have even set up competing political institutions and governments. Yet non-state actors may also rule and fight alongside state forces, or may even indirectly work to uphold state authority. In Syria, the Assad government has, as it were, informally outsourced or delegated violence and security to local pro-government defence groups and foreign militias, and it has withdrawn tactically and partially from shifting areas, in order to save resources for fighting and governing elsewhere. In Iraq, Kurdish Peshmerga and Shia militias were heavily mobilized to fight the Islamic State in lieu of Iraqi regular forces. Similarly, in North-Eastern Syria, where Assad regime forces maintain a modest military presence around the airport in Qamishli, internal security and border control are largely in the hands of the Kurdish forces, who partially coordinate security and governance with the regime (Collombier et al. 2018).

Across the four states Libya, Iraq, Syria and Yemen, all marked by war, armed groups are also engaged in typical state tasks in the fields of governance, service provision and collective goods. Rebels and militia groups are, for instance, providing healthcare, electricity and water to local populations. In Iraq, corruption and the inefficiency of the ethnic-sectarian Muhasasa system continue to haunt state institutions, ${ }^{8}$ while local and foreign militia groups and tribes are involved in a range of service provisions, including social benefits and local administration. This inevitably creates a vicious circle of state erosion, where local citizens seek services and security from armed non-state actors due to the inefficiency or absence of the state, which then further undermines the power and legitimacy of the latter. Weak state structures, one the one hand, create security vacuums that empower sub-state actors and lead people to fall back on communal ties - ethnic, sectarian, tribal - to guarantee safety and basic needs, which then further hollows out the state and heightens domestic security dilemmas (see Dodge 2014). On the other hand, state authority may also be partially upheld through outsourcing or delegation to non-state actors.

8 This is the sectarian quota system instituted after the US invasion in 2003, where government positions and ministerial posts are assigned according to prior agreements between the political-sectarian blocs (Sunni, Shia, Kurds) rather than according to merit or political views, thereby institutionalizing identity politics and enhancing sectarian patron-client relationships and corruption - as we also know from the Lebanese political system. 


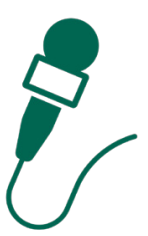

Interview with a member of Iraqi civil society: Iraq faces both risks and opportunities. The risks are that many politicians are corrupt and are not thinking what is best for Iraq but only of their own issues. The militias also have too much power and are able to intimidate citizens. But if we think about opportunities, we can say that Iraqi people are starting to realise that violence and killing will not solve any problems. They are moving away from sectarianism.

Armed conflict and the proliferation of armed non-state actors have similarly strengthened illegal economic networks across the region. In Libya, for instance, armed groups have taken advantage of their military might to join or build profiteering networks, composed of members of the state administration, politicians and businessmen. These militia cartels have diverted state funds and appointed key positions in state-owned companies (Collombier et al. 2018). In Iraq and Syria, proregime businessmen, militia leaders and their extended families are engaged in smuggling and illegal trade from regime-controlled to rebel-held areas, as well as in widespread racketeering, circumvention of international sanctions and drug-smuggling, just as illegal tribal networks proliferate in the border regions between Egypt and Libya (Malmvig 2018, Hüsken 2017). The new networks of militia-businessmen are heavily involved in the illegal war economy and closely linked to outside regional powers, such as Iran and Hezbollah in the case of Syria, or the SaudiArabia and the Emirates in the case of Yemen and Libya, serving further to undermine the formal institutions of state.

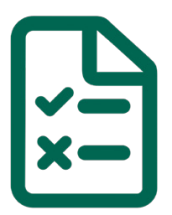

Delphi Survey with regional experts: Many have argued that the borders in the Middle East were drawn up arbitrarily. That is true in many parts of the region, but it is true as well in many other parts of the world. Moreover, it is hard to see how, given how entangled different ethnic communities are in the region, rewriting borders would lead to better political outcomes. In fact, it is more likely to be highly destabilizing politically.

States and non-state actors are, in short, engaged in rather complicated relations: at times, the latter are competing with or undermining state capacities, at others upholding or sharing state authority and the means of violence. The weakening of state institutions (internal sovereignty) does not, however, imply that we see a corresponding unravelling of the territorial nation-state lexternal sovereignty). Despite much debate on the end of the Sykes-Picot order, the present conflicts originating in the Arab uprisings were never about changing the nature of state boundaries, or creating new statelets, but about changing the nature of governments. ${ }^{9}$ The regional state system - and the national identities on which it is based - are far more resilient than has been widely

9 The exception is of course the Kurdish regional Government (KRG) in northern Iraq, which sought independence from Iraq after referendum in 2017, and the Islamic State, seeking a caliphate across present state boundaries. 
assumed (Del Sarto 2017a, Fawcett 2017). Rather, what we see is an enhanced permeability or blurring of the boundary between domestic and regional spheres. Sub-state actors are, for instance, allying with external patrons for financial or military support; regimes preoccupied with their own survival are drawing external powers into internal conflict, or they are engaged in erratic interventions or attempts to undermine the legitimacy of rival states. The repercussions of the permeability of some of the key states in the region will be discussed next.

\subsubsection{REGIONAL IMPLICATIONS}

The weakening of several states has had profound consequences not only for the relations between state and society (Boserup and Colombo 2017), but also for the shape of the regional order, where we see an intensification of the interplay between the domestic and regional levels and a rearticulation of the so-called Arab Cold War (Salloukh 2017: 660, Hazbun 2018, Kerr 1971, Valbjørn and Bank 2012). The permeability of several states has made it easier for domestic actors and armed groups to invite regional powers in, balance domestic opponents by aligning with external actors or use transnational bonds to gain external resources and support. Conversely, regional powers have sought to undermine their regional rivals and project their own power through the support of local clients in weak states, by enhancing transnational ties across states lethnic and sectarian), seeking to discredit rivals through transnational mobilization and/or projecting ideational power through sub-state or transnational entities.

In the early days of Arab uprisings, Qatar used Al Jazeera to rally support for international intervention and opposition movements close to the Muslim Brotherhood in Libya, Syria and Egypt. While Saudi Arabia and Qatar were both giving military and financial support to the armed opposition groups, they were soon backing rival factions as a result of their own geopolitical competition (Abboud 2016, Malmvig 2016b). In Bahrain and Yemen, Saudi Arabia - fearing Iranian influence and dissent from its own population - sent security forces to Manama to crack down on the protestors, just as Riyadh continues to lead a brutal war against the Houthis in Yemen. Similarly, Tehran feared that the fall of the Assad regime would spell the end of its strategic depth in Syria and Hezbollah's ability to deter Israel. It sent al Quds forces and numerous Shia militias from as far away as Pakistan and Afghanistan to fight alongside the Assad regime, in addition to Hezbollah, which requires weapons and supplies through Syrian territory to uphold its own unique position inside Lebanon's precarious power balance. Turkey - and to a lesser extent Israel - have also intervened heavily in Syria. Turkey has done so first on the side of the Free Syrian Army (FSA) and Muslim Brotherhood affiliated groups to augment its regional influence, and later to prevent Kurdish People's Protection Units (YPG), who have strong ties with Kurdish Kurdistan Worker's Party (PKK) in Turkey, gaining permanent territory and ultimately political autonomy in Northern Syria along the Turkish border. Paradoxically, in Iraq. Ankara has formed strong ties with the Kurdish Democratic Party (KDP) and the Kurdish regional government in Erbil, which the Barzani family uses to balance its local rival Patriotic Union of Kurdistan (PUK) and the central government in Baghdad, both being closer to Iran. For its part, Tehran has of course played a significant role in Iraqi politics and society since 2003 through its Shia religious institutions and support for Shia political leaders and militias, thereby projecting ideational power and creating strategic depth.

Wars and the fragmentation of central state power have thus created multiple cross-cutting relations and possibilities for intervention and meddling for all states in the region. Although a 
majority of states in MENA continue to be strong and with robust military apparatus (see Figure 2), and are not directly riven by war on their own soil, they are nevertheless deeply affected by the various conflicts in the region. Their sense of insecurity is thus heightened, and fearing that rivals might gain the upper hand from their patron-client relationships, they themselves engage in the same game, which of course only leads to rivals taking counter-measures, thereby repeating the classic security dilemma (see also Lynch 2018).

Figure 2 | Militarization in MENA: Soldiers per thousand inhabitants

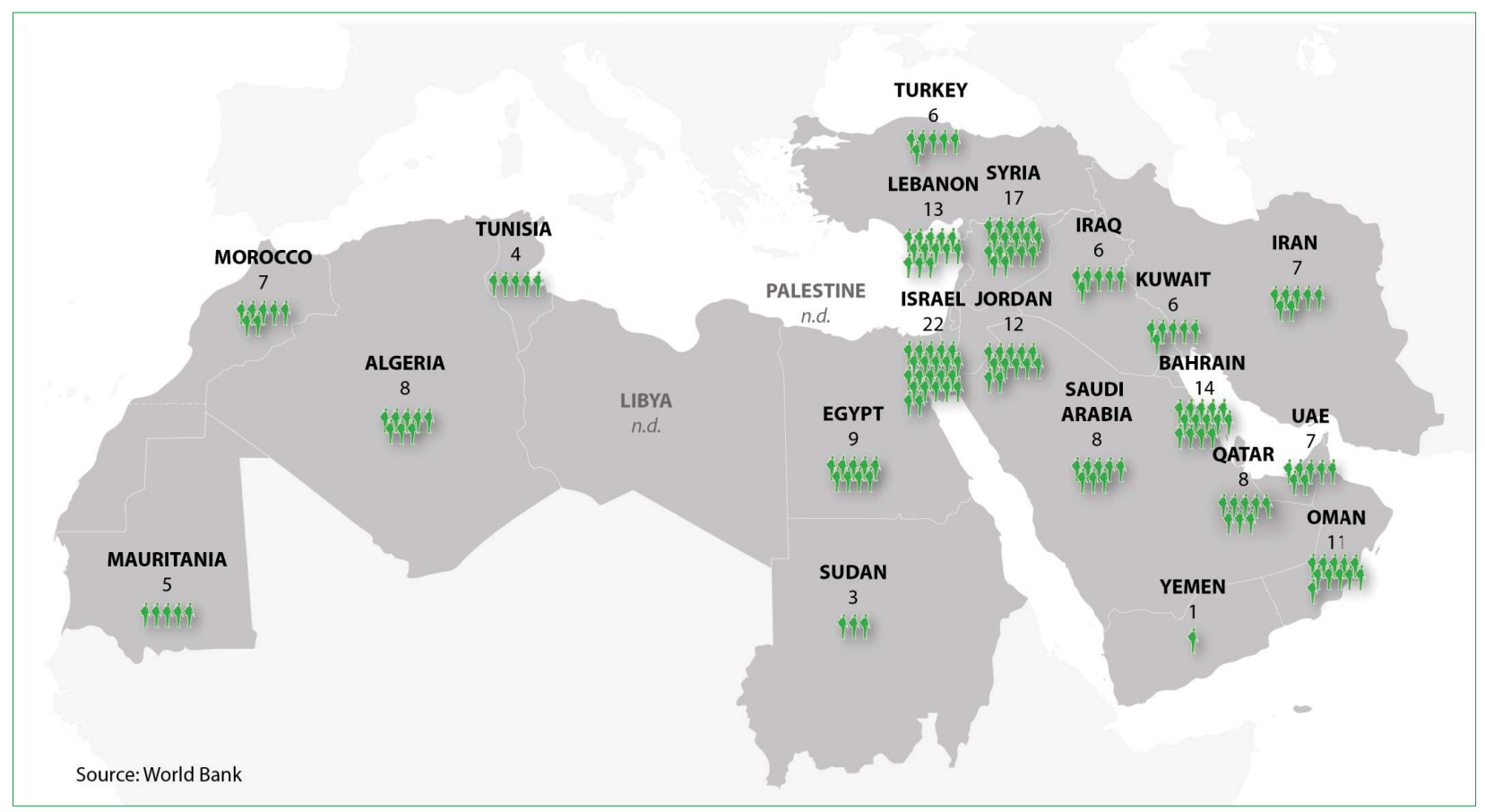

\subsection{REGIME INSECURITIES AND AUTHORITARIAN RESILIENCE}

At the same time, we see regimes - even in relatively strong states such as Saudi Arabia, Turkey and Egypt - being intensely preoccupied with their own security and threats to regime survival. Since the Arab uprisings, there has been a resurgence of authoritarian rule and authoritarian learning; a turn to illiberal policies in Turkey and Israel pre-dates the uprisings. Most incumbent rulers increasingly rely on coercive capacities, cracking down on dissenting voices, limiting press freedom and civil society actors' room for manoeuvre. A form of authoritarian learning has taken effect. ${ }^{10}$

Authoritarian rulers have looked to the fates of Mubarak and Assad, and now know that to preserve their regimes they should be willing to engage in mass repression and violence (Heydemann 2007.

10 Already in 2007 Heydemann (2007: 2) noted: “Lessons and strategies that originate within, and outside the Middle East, are diffused across the region, traveling from regime to regime and being modified in the process. Regimes learn from one another, often through explicit sharing of experiences [... e.g.] delegations traveling from one country to another to discuss issues such as how to manage the internet, respond to pressures for political reform, and ensure the fiscal autonomy of regimes". 
Lynch 2016 and 2018, Boserup and Colombo 2017). In Egypt, the economic and military elite from the era of Mubarak has largely been restored, press freedom is virtually absent and it is estimated that over 60,000 people are imprisoned on political grounds. ${ }^{11}$ As all over the region, opposition and dissenting voices are interpellated as terrorists. In Turkey, Erdoğan has moved away from liberal democratic ideals, and in Saudi Arabia superficial reforms are combined with large-scale arrest and harassment of, for example, women activists and Saudi dissidents abroad and even penalties for banal tweets that do not mention the blockade of Qatar in positive ways (Aziza 2019). Crown Prince Mohamed bin Salman's hypocritical reform practices echo what Heydemann prior to the Arab uprisings convincingly called "authoritarian upgrading", where regimes seemingly open up and reform a specific limited sector, while simultaneously cracking down and increasing repression in others (Heydemann 2007).

Regimes' obsession with remaining in power have intensified dynamics in which perceived threats to regime survival are balanced by often erratic foreign policies and ever-shifting alliances (Gause 2003, Rubin 2014). Saudi Arabia's blockade of Qatar and its war in Yemen, or the al-Sisi regime's concerns with terrorists and the Muslim Brotherhood paving the way for military strikes in Libya or cooperation with Israel in the Sinai, are all examples of the close entanglement of regime survival concerns and foreign policies. Although Israel is different insofar as it is not ruled by an authoritarian government, similar traits can be observed. The Netanyahu government's major preoccupation with Iran and the creation of a heightened sense of insecurity have, for instance, allowed the neo-right-wing government to divert attention away from the unresolved conflict with the Palestinians, the expansion of Israeli settlements in Palestinian territories and, more recently, corruption charges against Netanyahu. Ultimately, the Israeli government's "politics of insecurity" (Del Sarto 2017b) have allowed Netanyahu to stay in power.

\subsection{ETHNO-SECTARIAN SECURITIZATION}

One of the ways whereby regimes in the region have propped up their power and tried to guarantee survival, even before 2011, is through the instrumentalization of sectarian identities. By manipulating fears of political exclusion, claiming to protect certain sections of the population from others, or using sectarianism to discredit their political opponents and rivals, sectarian entrepreneurs and political leaders have enhanced their power and deflected demands for political change (Hashemi and Postel 2017: 5). Sectarianism is of course not new to the region. It is firmly institutionalized in Lebanon's political system and clientelist networks, and since the 2003 US invasion it has been a strong feature of Iraq's divided politics and society, just as monarchies in the Gulf such as the Khalifa family in Bahrain and the Al Saud family in Saudi Arabia have enacted power through divide-and-rule tactics over their Shia populations for decades (Haddad 2011, Salloukh 2017, Moore-Gilbert 2016). But until recently, sectarianism was largely dismissed and denied in official discourse, as political leaders and government officials would often delicately balance between using subtle sectarian strategies, and at the same time seeking to contain and silence overt sectarianism (Salamandra 2013, Haddad 2011, Malmvig 2019). With the destruction of the Iraqi state in the wake of US invasion and the institutionalization of sectarianism in the new Iraqi political system, sectarianism grew more widespread. As the Iraqi state crumbled, it provided ample room for a mix of transnational jihadist groups, Iranian-backed Shia militias and a host of

11 According to Human Rights Watch (2019). 
other foreign players. In the end, as Hinnebusch notes, the Iraq conflict spilled over in the region, transnationalized sectarian conflict and stimulated a new sectarianized discourse (Hinnebusch 2016).

Yet, the Arab uprisings seem to have even further widened and deepened sectarianism (Malmvig 2014, Gause 2014, Valbjørn 2018). In Bahrain, as in Syria, the demonstrations were initially crosssectarian, with protesters yelling "neither Sunni nor Shia, we are one". But the Khalifa government and state media skilfully promoted the narrative that this was a Shi' i uprising orchestrated by Tehran and demonstrators no more than Shi'i traitors and rioters, who were targeting Sunnis (Matthiesen 2017: 208, Moore-Gilbert 2016). This proved effective and created its own self-fulfilling prophesy, as Sunni protesters stayed at home and Saudi and United Arab Emirates (UAE) security forces moved in, unleashing the fiercest crack-down in Bahraini history (Matthiesen 2017). In the wake of the uprisings, Saudi Arabia itself exaggerated sectarian differences inside the kingdom as a form of counter-revolutionary strategy to prevent national non-sectarian platforms from developing (Al-Rasheed 2017: 143). Even in countries without significant sectarian minority groups, such as Egypt and Jordan, there have been occasional attacks on Shias and a heightened anti-Shia rhetoric on social media platforms (Valbjørn 2017: 53). Adding to the sectarian hate speech and fearmongering online are Sunni jihadi groups, such as Hayat Tahrir al Sham in Syria, local al Qaedaaffiliated groups and previously the Islamic State, who engage in extreme sectarian practices and discourses, viewing Shias as apostates that legitimately can be killed (takfir). Conversely, the mobilization of transnational Shia militias from as far away as Pakistan and Afghanistan fighting together on the battlefields of Syria and Iraq have added to Sunni perceptions and fears of being under attack in their own countries.

We have thus been witness to how sectarian identities have become increasingly securitized, being articulated as under threat or threatening (Malmvig 2014 and 2016a, Darwich and Fakhoury 2016), with this legitimizing the use of exceptional means such as violence and fierce repression (Wæver 1995). Though the securitization of sectarian identities in this sense is deliberate, once unleashed securitization constructs hard social facts and self-fulfilling prophecies. Fear-mongering and sectarian Othering end up creating self-perpetuating in-out group dynamics and social realities that become difficult to roll back, as we have seen in Iraq and Syria (Hinnebusch 2016, Phillips and Valbjørn 2018). In Syria, the Assad regime already in 2011 characterized demonstrators and opposition as Sunni sectarian Islamists and terrorists, who would establish Sunni majority rule, while the regime shabiha ${ }^{12}$ delivered sandbags to Alawite villages allegedly to protect them from Sunni rampage - thereby installing sectarian fears among minority groups and again creating self-fulfilling prophesies (Salamandra 2013). The classic security dilemma led to more violent forms of sectarianism with several massacres of Sunnis in 2012 (Phillips and Valbjørn 2018) as a spiral of sectarian violence was set in motion. Today, the young generation of soldiers and militia who have fought in Syria for years are more openly sectarian and seem oblivious to previous official narratives of a Syrian national "mosaic" of ethno-sectarian identities lauthor interview with Syrian FSA fighters, September 2017, and interview with Samer Yazbek, 2015).

12 Meaning "ghosts" in Arabic, civilian gangs or militias loyal to the Assad government that were used after 2011 to intimidate and crack down on opposition and dissent. 
Thus, sectarian securitization is not without risk. While regimes and sectarian entrepreneurs may use securitization of sectarian identities to increase their power base, these identity manipulations may paradoxically undermine their very power and legitimacy in the long run lalso Del Sarto 2018). In Syria, for instance, the Assad regime may find it difficult to curb the influence of Shia militias in the coming post-conflict and reconciliation phase; and in Iraq, the government is widely seen as sectarian (even by some Shia parties and religious leaders) and without legitimacy as a result. Furthermore, the securitization of ethnic and religious identities creates antagonism and makes for fearful societies, which collide with ideas of individual rights, citizenship and inclusivity, working to the disadvantage of ethnic and religious minorities in the longer term. In Bahrain and Syria, the incumbent rulers may have succeeded in aggravating sectarian divides to the extent that it is unclear whether they are able to overcome a situation of fractured and unstable communities, haunted by suspicion and unrest (Moore-Gilbert 2016).

\section{REGIONAL DYNAMICS: POLARITY, PATTERNS OF AMITY AND ENMITY, ALLIANCES AND GEOPOLITICAL SHIFTS}

Although regional dynamics are constantly shaped by domestic and global factors, some of the features of the regional order (and the challenges it may face) have to be analysed as largely autonomous phenomena. The Arab uprisings in 2011 and before, and the US invasion of Iraq in 2003, have altered the patterns of polarity, amity/enmity and regional cooperation. The following sections assess the intensity and nature of these changes as well as the shifting centres of gravity in the MENA region.

\subsection{PATTERNS OF MULTIPOLARITY: BEYOND THE SAUDI-IRANIAN CONFRONTATION}

According to Buzan and Wæver (2003), the number of regional powers defines the polarity of any regional security complex. Thus, there are unipolar regions (with a dominant hegemonic power), bipolar regions (structured around the competition between two powers) and multipolar regions. Multipolarity has been associated with both conflict among its members and autonomy vis-à-vis global powers (Lake and Morgan 1997). The absence of a dominant or hegemonic regional power (Lustick 1997), together with the interference of major global powers, is seen as producing various forms of insecurity (Makdisi 2017, Makdisi et al. 2017, Hazbun 2018).

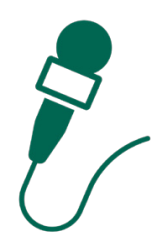

Interview with an expert in Qatar: There are no dominant or hegemonic players any more. There are many actors that compete with each other and this makes political outcomes more unforeseeable.

To assess the nature and extent of the changes in the multipolarity of the Middle East since 2011, we need to open up the concept of multipolarity to take into account not only the number 
of poles, but also the nature of the major powers and the types of interaction among them. This implies looking at whether there is a hierarchy among these poles (Organski 1958, Lake 2009), analysing changes in the material and ideational power of the regional actors and assessing the capacities to deploy power (Nolte 2010: 883, Haas 2014). Such an analysis also needs to consider variations in terms of ambition and the capacity to translate this ambition into regional influence (Stephen 2002, Önis and Kutlay 2013) and the evolving relationship between the regional powers and the global order (Hurrel 2016). Moreover, to capture some of the recent changes that have shaped the regional order, it is useful to differentiate between different types of regional powers. We may draw a distinction between (1) full-fledged regional powers, (2) niche regional powers and (3) proximate regional powers. Full-fledged regional powers have stakes in different conflicts or cooperation schemes all across the region and they combine instruments of soft and hard power. Niche regional powers exert a region-wide influence, but only in some specific domains (political, security, economy, ideational). Conversely, the influence of proximate regional powers is constrained to one of the sub-regional systems (such as the Maghreb, the Levant and Gulf in this case); these regional powers may retain some influence vis-à-vis their closest neighbours but play a minor role in key regional conflicts.

The MENA region is a multipolar system due to the presence of at least five states that claim to be or tend to act as full-fledged regional powers: Saudi Arabia, Egypt, Israel, Iran and Turkey. The confrontation between Saudi Arabia and Iran is often identified as the dominant driver in regional geopolitics at present. There is no doubt that Riyadh and Tehran have been using their local (and partly newly recruited) proxies not only to win regional influence but also to prevent their rivals from doing the same (see, among others: Nasr 2007, Salloukh 2013, Abdo 2017). A focus on the centrality of the hostility between Riyadh and Tehran, which has been intensifying since the 2003 US invasion of Iraq, thus tends to emphasize that bipolar dynamics are gaining ground, and how these enhance the conflict potential of the region. While Iran and Saudi Arabia have further increased their regional clout after 2011, changes in the regional order are not only related to the intensification of the Iran-Saudi rivalry but also to the growing ambition and capacity of a number of additional regional players to project power. A case in point is Turkey. Turning into a full-fledged regional power, Ankara started to project its influence in areas where it had a lowkey presence hitherto, such as the Maghreb. Turkey also became strongly involved in the Gulf Cooperation Council (GCC) crisis, including through the deployment of additional Turkish troops to Qatar in 2017. In this same period, both Qatar and the UAE started to act as genuine and fullfledged regional powers, resorting to both hard and soft power tools and exerting a strong political influence beyond their immediate vicinity.

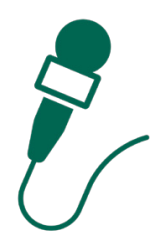

Interview with an opposition politician in Lebanon: The traditional and most influential actors in the region are the Saudis and Iran. They have been shaping and continue to shape the region. But there are the new actors. One of them is the UAE due to its ambitious policies and willingness to expand control in the region. 
Conversely, since the 1970s, but even more so since 2011, Egypt has reduced its capacity to lead and project influence beyond its immediate neighbours (Libya, Nile Basin, Palestine, Eastern Mediterranean dynamics). As a niche regional power, Egypt is a rather secondary actor when it comes to Syria, Yemen, Iraq and the Maghreb (with the exception of Libya). Moreover, since 2011 Cairo's financial autonomy from its Gulf donors has diminished noticeably. Finally, as a consequence of the major geopolitical shifts that occurred in 2003 and 2011, countries that used to play a strong regional role became subordinated to the agenda of other regional powers and were largely overlaid by geopolitical rivalries. Iraq and Syria are the best examples here.

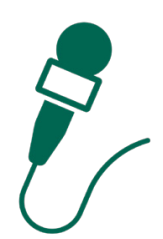

Interview with an EU official: The relatively new heavyweights on the regional scene are those that used to be payers at best and now are players: Saudi Arabia, the UAE and Qatar. The doubt is whether this new role is sustainable.

In contrast, polarity dynamics in the Maghreb have been rather stable despite major changes at the level of state-society relations and the collapse of one of the states of the region, that is, Libya. The long-lasting rivalry between Algeria and Morocco resulted in strong and durable bipolar dynamics that have not been significantly altered by the geopolitical shifts in the Middle East (Lounnas and Messari 2018, Hernando de Larramendi 2018).

Thus, while the rivalry between Saudi Arabia and Iran pre-dates the Arab uprisings, the latter led to its intensification. Furthermore, the 2011 uprisings fostered the ambitions and willingness of a number of additional regional players to deploy material and ideational means to project their influence, such as Turkey, Qatar and the UAE. Other regional actors, most notably Syria, Libya and to a lesser extent Egypt, lost their influence after 2011. But rather than moving towards an Iran-Saudi bipolarity, the MENA system is still marked by a multipolar order, which may be characterized as "fragmented" or "competitive" multipolarity (Hinnebusch 2014: 51, Kausch 2014). Patterns of amity and enmity are characterized by several overlapping cleavages, which exacerbate or neutralize one another, as will be outlined in the next section.

\subsection{PATTERNS OF AMITY AND ENMITY: OVERLAPPING AND MULTI-LAYERED CLEAVAGES}

Patterns of amity and enmity allude to constellations of friendships and hatred as well as to specific issues that trigger conflict or cooperation among actors. As observed by Buzan and Wæver (2003: 50), "these patterns of amity and enmity are influenced by various background factors such as history, culture, religion and geography, but to a large extent they are path-dependent and thus become their own best explanation". From this perspective, amity refers to relations that range from friendship to expectations of protection and support, and conversely, enmity refers to relations of fear, hatred and distrust. Regional systems can be structured around a dominant amity/enmity pattern or a plurality of them. The MENA region is marked by the latter. 
The most relevant cleavages revolve around the question of accepting Israel as a regional player, ethno-religious fragmentation and the ideological clash between those adhering to the status quo and revisionist or revolutionary forces. This section assesses three main changes in the way these cleavages are shaping patterns of amity and enmity in the MENA region since 2011. These are: (1) the growing openness of some regional actors to establishing links with Israel and publically acknowledge the existence of common interests; (2) sectarianism and the securitization of identities; (3) the ideological antagonism between supporters of political transitions loften associated with the backing of groups linked to the Muslim Brotherhood) and defenders of the status quo. The latter is often linked to the perception of the Muslim Brotherhood as a domestic threat.

\subsubsection{THE ARAB-ISRAELI CONFLICT AND THE NORM OF ARAB UNITY}

Pan-Arabism and the idea of Arab unity had its heyday in the 1950s and 1960s, serving as a powerful structuring force of inter-Arab and regional politics in the Middle East (Jankowski and Gershoni 1997, Barnett 1998, Dawisha 2003). Of course, in reality the idea that "Arab interests" had precedence over the interests of the territorially defined Arab states and that, ultimately, all Arabicspeaking territories should merge into a single Arab nation-state was fervently contested. ${ }^{13}$ The latter view, maintained by the nominally socialist republics led by Egypt's Gamal Abd-el Nasser, clashed with the preferences of the Arab monarchies, as analysed by Malcolm Kerr (1971) in what he famously termed the "Arab Cold War". Most Arab kingdoms subscribed to a milder form of Arab nationalism at best, limited to Arab interstate cooperation and solidarity. In fact, in the Arab political arena in those years, pan-Arabism served as a tool to legitimize leadership ambitions within the Arab state system and to justify regional hegemony aspirations, of which Nasser was a champion. Struggles for pan-Arab leadership masked inherent state fragility, led to conflicts, justified mutual assaults on sovereignty and, perhaps paradoxically, weakened the Arab state system (Solingen 2007: 771-2, Barnett 1998). But the idea of pan-Arab solidarity, in which the Palestinian cause was central, widely resonated with Arab publics, thus conditioning the foreign policy of many states in the region - often against far more narrowly defined national interests (e.g. Jankowski 1997, Barnett 1998: 158 ff.). Yet altogether, the history of the Israeli-Palestinian conflict shows that the commitment to the Palestinian cause of Arab leaders was usually more rhetorical than factual (e.g. Tessler 2009).

The defeat of the Arab armies by Israel in the 1967 war marked the beginning of the end of secular pan-Arabism (Ajami 1998, Dawisha 2003). Subsequent events, such as Egypt's 1979 separate peace deal with Israel and Iraq's invasion of Kuwait in 1990, would indicate that Arab regimes felt no longer compelled by the idea of Arab unity and solidarity - in spite of occasional lip service to it. This development would continue in the 2000s, with some Arab regimes (notably Egypt, Jordan and Saudi Arabial holding the Lebanese Hezbollah responsible for the 2006 war with Israel. Israel's three wars on the Hamas-ruled Gaza Strip witnessed a replay of these inter-Arab divisions: Egypt and Saudi Arabia accused Hamas of being a pawn of Iran. At the same time, however, after 1967 the question of Palestine would continue to impact on regional politics as it witnessed the (re) configuration of those state and non-state actors that define themselves as part of the "resistance

13 The merger of Egypt and Syria into the United Arab Republic in 1958 exemplified the aspirations for territorial unity, but the experiment only lasted for three years. 
axis" against Israel's persistent rule over the Palestinians. Often termed by the West as "radical" or "extremist" states or groups, this axis included Iran, Syria under the Assad regime, different (and partly Islamist) Palestinian factions and the Lebanese Hezbollah (e.g. Makdisi 2018).

After the Arab uprisings, the fragmentation of the Arab state system and the decreasing relevance of the norm of Arab unity and solidarity has been continuing, with the Syrian civil war and the crisis between Qatar and Saudi Arabia being perhaps the most prominent cases in point. The Arab-Israeli conflict, and more specifically the question of Palestine, "the major issue of regional concern across the Middle East for over a century" (Makdisi 2018: 3), lost its relevance as a major structuring factor in Middle East politics; it still plays a role but is no longer at the centre of attention. Common Arab positions on how to resolve the Arab-Israeli conflict, such as those expressed in the 2002 Arab Peace Plan, are no longer relevant. The aftermath of the 2003 US invasion of Iraq and particularly the growing antagonism between Saudi Arabia and Iran have prompted the intensification of the Sunni-Shia divide, whereby Saudi Arabia's fuelling of sectarianism can be read as the kingdom's pre-emptive counter-revolutionary strategy in response to the Arab uprisings (Al-Rasheed 2017). Concurrently, anti-Zionism has ceased to be one of the defining features of Arab politics. Instead, shared hostility towards Iran and its allies has been forging a new rapprochement between Israel and a number of Arab states in the region, most notably Saudi Arabia, Egypt, the UAE and some smaller Gulf monarchies.

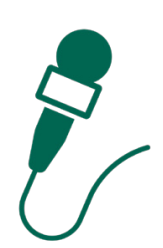

Interview with a foreign expert in Qatar: One of the main elements that will change the region is the new Arab-Israeli alliance against Iran.

In this vein, a Bahraini non-governmental delegation, carrying a sign "This Is Bahrain", visited Jerusalem in December 2017 (Henderson 2017), the same month in which Saudi Crown Prince Mohamed Bin Salman reportedly told Palestinian President Mahmoud Abbas to accept an unofficial US peace plan that follows the preferences of Israel's right-wing governments (Barnard et al. 2017). ${ }^{14}$ While there are (still) no diplomatic relations between Saudi Arabia and Israel, the relationship between Riyadh and the government in Jerusalem has undoubtedly warmed up, also due to the friendship between the young and overconfident Saudi crown prince and the equally young and unexperienced Jared Kushner, US President Trump's son-in-law and adviser on the Middle East. Kushner is close to the worldview of Israeli premier Netanyahu. In early 2018, the powerful Saudi crown prince declared in an interview with The Atlantic that "there are a lot of interests we share with Israel" and that "the Palestinians and the Israelis have the right to have their own land" (Goldberg 2018) - unprecedented statements for an Arab leader whose country is officially still at war with Israel. In October 2018, Netanyahu made an unannounced trip to Oman and met Sultan

14 This "peace plan" apparently stipulates a Palestinian state with non-contiguous parts of the West Bank and only limited sovereignty over their own territory and without East Jerusalem as the capital; no Israeli settlement evacuation; and no right of return for Palestinian refugees. 
Qaboos. ${ }^{15}$ A few days later, Israeli Culture and Sports Minister Miri Regev visited Abu Dhabi to attend an international judo competition, and the Israeli anthem was played as an Israeli judoka won the gold medal (Katzir 2018). The Emirates already host an Israeli diplomatic mission, which is accredited to the Abu Dhabi-based International Renewable Energy Agency (Henderson 2017). And in January 2019, in the popular CBS interview program "60 Minutes", Egyptian President Abdel Fattah al-Sisi acknowledged the ever-closer covert military and intelligence cooperation with Israel, which also includes hundreds of secret Israeli air strikes against Egyptian insurgents in the Sinai Peninsula (Kirkpatrick 2019). ${ }^{16}$ It is also interesting to note that President Trump's decision to move the US embassy from Tel Aviv to Jerusalem in May 2018 was met with a rather tepid condemnation by Arab leaders.

In fact, Israel has drawn many advantages from regional developments since the Arab uprisings. In addition to improved relations with Saudi Arabia and the Gulf monarchies land their shared antagonism vis-à-vis Iran), the Assad regime is no longer a threat to Israel (in case it ever was): ${ }^{17}$ Hezbollah, for now, is preoccupied with fighting in Syria; and Egypt under al-Sisi shares Israel's dislike for Hamas. Israel is of course concerned with the presence of Hezbollah and Iranian forces on neighbouring Syrian territory, particularly where close to its borders, as well as with Hezbollah's extensive battle experience gained in Syria. But altogether, Israel's position in the regional system has undoubtedly grown stronger. The popular appeal of the "axis of resistance" has been weakened, mainly because of the involvement of Iran and Hezbollah in the Syrian civil war and the raging conflict in Syria itself. Last but not least, the policies of Israel's right-wing government have the full support of the US administration under President Trump (Quero and Dessì 2019).

But while today pan-Arab unity schemes that would lead to major changes in the existing state system are no longer an objective of Arab leaders, it would be premature to dismiss the Arab dimension of regional politics altogether, as convincingly argued by Valbjørn and Bank (2012). References to the "Arab cause" are still relevant for Arab leaders, with the non-Arab states Iran and Turkey entering the fray of Arab/regional politics by presenting themselves as the true defenders of the Palestinians. Second, non-state actors, most notably Hezbollah and Hamas, have taken on the role of championing the Palestinian cause. Third, unlike the secularist tradition of pan-Arabism of the 1950s and 1960s, the Arab dimension of Middle East politics is increasingly embedded in a religious/pan-Islamist discourse. Finally, and perhaps most importantly, the norm of Arab solidarity and the Palestinian cause still resonate very much with Arab publics. The strong reactions of Arab populations to Israel's war on the Lebanese Hezbollah in 2006 and on the Hamasruled Gaza Strip in 2008-9 are evidence of this (Valbjørn and Bank 2012). In the context of the role of social media and an integrated Arab media market, the Arab uprisings and their aftermath were an additional proof of the societal and cultural interconnectedness of Arab populations, which seems to have only increased (also Noble 2008, Lynch 2016). Indeed, the growing importance of

15 “Israel's Netanyahu Meets Sultan Qaboos in Surprise Oman Trip”, in Al Jazeera, 26 October 2018, http://aje.io/ nezwd.

16 Egypt subsequently tried to block the broadcast, unsuccessfully though.

17 While the border between Israel and Syria on the Golan has been quiet for decades, Assad was considered "the devil we know" in Israel. This explain the quarrels within Israel's political and military establishment on whether to support the Syrian opposition once the civil war in Syria started. 
Arab satellite and social media over the last decade(s) have created an Arab "echo chamber", where Arab solidarity and the Palestinian cause still matter a great deal. Popular support for the Palestinians has been continuing in spite of shifting regional alignments at the state level lalso Makdisi 2018: 2). The persistent relevance of the Palestinian cause among Arab populations points (once more) to an ever-growing disconnect between Arab regimes and their populations - a widening of the "regimes-people divide", identified by some scholars over a decade ago (Lynch 2006).

The weakening norm of Arab unity, the diminished relevance of the Arab-Israeli conflict in general and the question of Palestine in particular for regional politics at the state level, and the shifting positions of a number of Arab states as regards relations with Israel are important changes within the current regional order in MENA. Institutionalized relations between Israel and a growing number of Arab states - which are not Israel's immediate neighbours - would point to a change of the regional order. In other words, we would witness a rather radical transformation of the regional order if formal relations with Israel became the norm, or if Palestine was no longer mobilizing Arab public opinion.

\subsubsection{SECTARIAN SECURITIZATION AT A REGIONAL SCALE}

At the regional level, states and sub-state actors have similarly used sectarian identity politics in their power struggles with enemy states, and as a forceful tool for transnational mobilization. Sectarianbased politics and conflicts have provided ample opportunities for competitive intervention and meddling. Saudi Arabia, for instance, has widely employed sectarian Othering to mobilize local clients in conflict zones in Yemen, Iraq or Syria and as a way to discredit Iran le.g. Gause 2014: 5, Ayub 2013, Hashemi and Postel 2017: 21). Iran and Hezbollah have similarly engaged in sectarian fear-mongering to mobilize Shia fighters for war and to gather support for their interventions, while attempting to de-legitimize Saudi Arabia and actors linked to Riyadh by framing these in sectarian terms as Wahhabis, Sunni extremists or so-called takfiris (see also Malmvig 2019). This is an important difference compared to the pre-2011 era, where Iran successfully employed the "resistance axis narrative" and often downplayed sectarian differences between Sunni and Shia. Also Turkey, which traditionally has refrained from legitimizing its regional policies in sectarian terms, is increasingly resorting to sectarian language, just as jihadi networks and social media have amplified sectarian worldviews. We thus see an increased number of regional powers employing a more explicit sectarian language, softening what was once a well-established "sectarian taboo" or non-sectarian norm that constrained the use of aggressive sectarianism in the region (Haddad 2011, Malmvig 2019).

Sectarian-based intervention and transnational mobilization have in this way heightened conflict patterns in the region and exacerbated the permeability of states (Hinnebusch 2016). By aligning with sectarian sub-state groups, regional powers have contributed to undermining state orders and blurred the boundaries between the domestic and regional spheres, as various state and non-state actors are linked through powerful identity dynamics and categories lalso Del Sarto 2019). But this is a two-way street: The sectarian conflict dynamics in, for example, Syria, Yemen or Iraq have also contributed to intensifying the rivalry between Saudi Arabia and Iran and their respective allies, thus deepening regional conflicts and lines of enmity. While there are some obvious parallels to the Arab Cold War of the 1950s and 1960s, where revolutionary pan-Arabism 
and socialist Arab ideologies similarly were used for cross-border mobilization, intervention and fierce meddling, today's securitization of ethno-religious identities may denote qualitatively different conflict dynamics and a re-conceptualization of "interest". When securitizing actors frame the Other as a sectarian enemy, the latter is to be fought, or even eliminated, not because of conflicting strategic interests or different versions of raison d'état, but because of the enemy's very identity and/or beliefs (Malmvig 2016b). When conflicts are framed in terms of the survival of specific ethnic or religious groups, "objective" war aims seem to recede into the background, and de-escalation or compromise are more difficult to achieve. The securitization of identities may also ignite new conflicts, because securitized identities entail fear and victimhood, which can be easily exploited further down the line (also Del Sarto 2018).

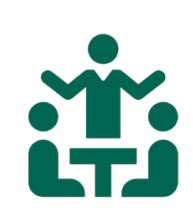

Beirut Focus Group: The spread of sectarianism and the prolongation of Saudi-Iranian rivalry is dangerous. The recent sectarian tensions in the region, especially in Iraq and Syria, increase the probability of larger wars between Iran and Saudi Arabia. A direct war threatening the security of the Gulf and the flow of oil is not very likely but the manipulation of sectarian tensions are.

However, explanations of regional politics based on simple notions of Sunni-Shia antagonisms are undoubtedly too simple and may even lead to dangerous policy prescriptions, such as breaking up states along ethno-sectarian lines, fortifying autocratic governments' repressive practices or reinforcing Orientalist understandings of the Middle East as "all about religion" and conflicts as therefore endemic to the region. There are indeed several factors that mitigate and cut across Sunni-Shia dynamics. Regionally, alliances and rivalries continue to be guided by realist strategic interest and balances of power considerations, rather than sectarian affiliation or belonging. For instance, Iran, Hezbollah and the Assad regime are once again allied with “Sunni" Hamas; just as the close ties between the Assad regime and Tehran are firmly rooted in the geostrategic importance of Syria for Iran's deterrence of Israel. The Assad regime may be dominated by Alawites, but it has strong ties with Christian, Druze and other minority groups, and it has largely co-opted the affluent Sunni business class as well as appropriated some of the religious practices of Sunnis, while at the same time often posing as secularly minded (see, e.g., Salamandra 2004, Phillips 2015). Similarly, in order to understand why several Arab governments are moving closer to Israel, sectarian affiliations obviously have little explanatory power, while common threat perceptions are key. Although Saudi Arabia projects itself as leader of a regional Sunni alliance, Qatar and Turkey would certainly disagree - and they both continue to entertain foreign policies and ties with Tehran independently of Riyadh. This, in sum, makes it difficult to speak of any coherent "Sunni camp" or opposing Shia alliance in Middle East regional politics today.

So, at a time when references to core Arab norms or pan-Arab identities have lost most of their transnational appeal and mobilizing capacity, sectarian referents seem to offer a (novel) sense of authenticity and common sectarian history, which state and sub-state actors can use in their competitive interventions and regional power games. Once unleashed, fears of the sectarian "Other" are difficult to roll back, and sectarian identity conflicts may prove more intractable and 
entrenched. Yet, Sunni-Shia divisions are only one among several cross-cutting lines of enmity and amity in the present Middle East, and alliance-formations and rivalries are strongly influenced and mitigated by non-sectarian factors.

\subsubsection{CHANGE VERSUS STATUS QUO}

The re-articulation of a region-wide rivalry between actors welcoming the fall of authoritarian regimes in several countries of the region and those that were resistant to it is one of the new aspects of the post-2011 context. To a large extent, this positioning was connected to whether they perceived it as an opportunity to expand their regional influence or a threat to the survival of their own regimes. The ideological confrontation scaled up after Morsi's ousting in Egypt in July 2013, thus setting up a region-wide ideological confrontation between Qatar and Turkey, on the one hand, and the UAE, Saudi Arabia and Egypt, on the other. This situation has been depicted as a "intraSunni Cold-War" (Gause 2014) or a "new Arab Cold War" (Valbjørn and Bank 2012, Khoury 2013, Ryan 2015, Salloukh 2017: 660, Hazbun 2018), thus evoking the ideological confrontation between revolutionary republics (led by Egypt) against conservative monarchies (led by Saudi Arabia) that shaped the regional order since the mid-1950s up until Nasser's death in 1970. During this period, regional powers meddled in the domestic politics of their neighbours, thereby increasing regime insecurity and the need to balance those threats (Kerr 1971, Walt 1987). After 2011, we see indications of similar dynamics materializing.

The regional tug of war between two ideologically aligned camps manifested itself both in the involvement of regional powers in political transitions, but also in the support to rival parties in regional conflicts. The fall of autocratic leaders and the initiation of political transitions in North Africa resulted in the strengthening of the Muslim Brotherhood as a transnational political actor (see Figure 3). Two of the rising regional powers, Qatar and Turkey, welcomed these developments. However, Doha and Ankara did not frame them as the result of ideological solidarity, but rather as efforts to back popular aspirations and support political change. For instance, the then Turkish foreign affairs minister Ahmed Davutoglu announced a strategic alliance between both countries framed as "the Axis of Democracy" underpinning a "new order" for the region as a whole (see, for instance, Shadid 2011).

In contrast, Saudi Arabia and the UAE initially supported authoritarian regimes so that they could resist pressure. They would later deploy financial and political support to the domestic rivals of the Muslim Brothers. For instance, the UAE supported the anti-Ennahda movements in Tunisia, while Saudi Arabia and the UAE provided strong support to the rule of al-Sisi following the toppling of the Muslim Brotherhood government in $2013 .{ }^{18}$ Again, this was not framed as an anti-democracy stance, but as a need to provide stability and fight terrorism.

18 Qatar quickly withdrew its financial support but Saudi Arabia and the Emirates filled the vacuum, announcing the disbursement of 8 billion US dollars in aid in different forms. This injection of liquidity was vital to keeping the economy afloat. 
Figure 3 | Islamist parties' performance in North African elections (2011-2017)

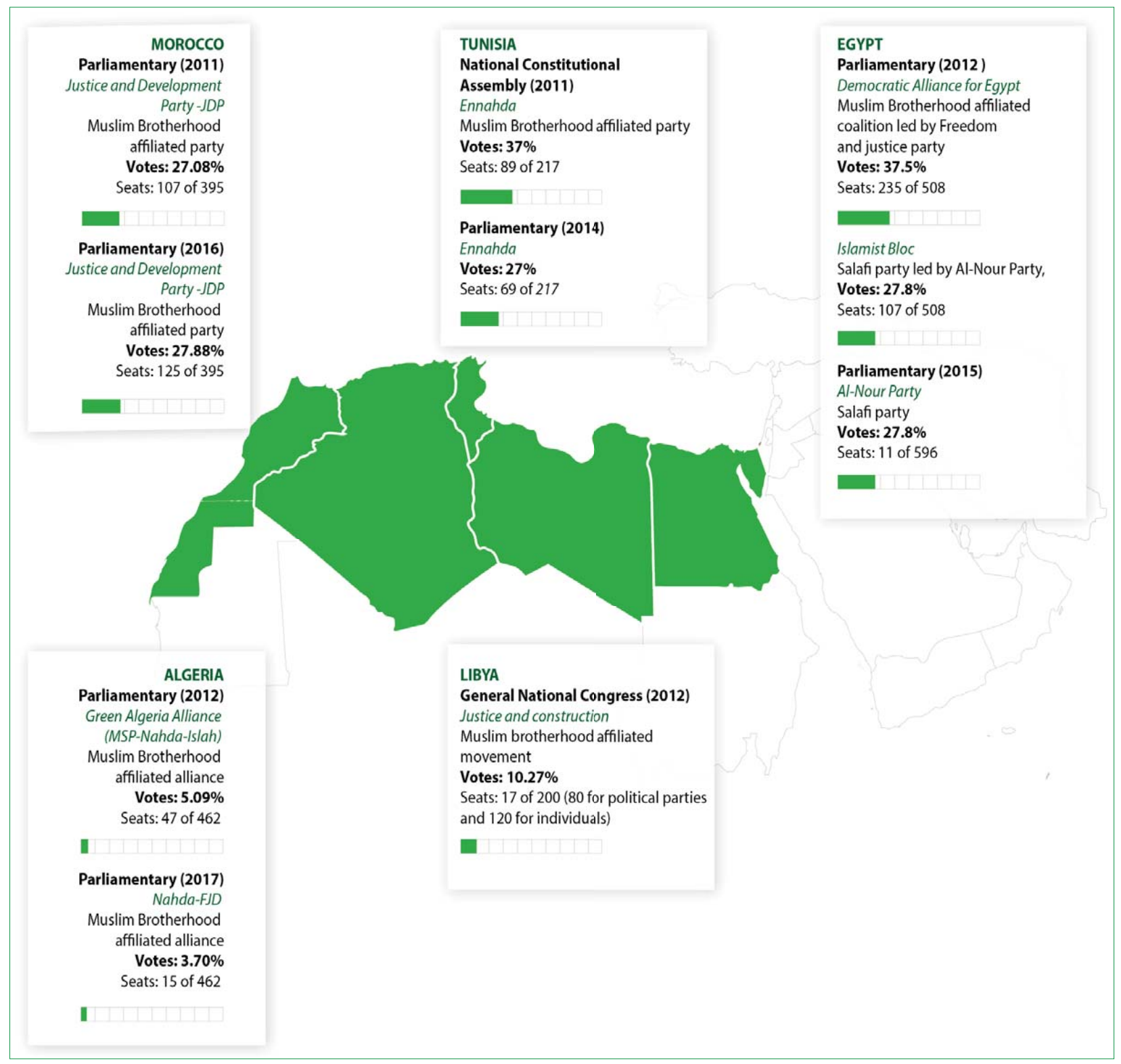

Note: In Egypt and Libya there are two kinds of seats: those dedicated to political parties and those dedicated to individuals. In other words political parties and individuals compete for different seats.

Created by CIDOB. Source: Authors.

The rivalry is also apparent in the way regional powers position themselves vis-à-vis regional conflicts. This is certainly not the first time that regional actors have intervened and meddled in the affairs of other states along ideological lines: in previous decades, regional powers have, for instance, backed different Palestinian factions, with Egypt supporting Fatah and Turkey and Qatar maintaining good relations with Hamas. Post-2011 the two regional conflicts, where this ideological rivalry has been most visible, are Syria and Libya. One of the game-changers of the war in Syria was the formation of transnational alliances "among many different kinds of actors 
[that] included big and medium-sized regional powers, local state and non-state actors and international powers" (Khouri 2018: 4). Several powers supported opposition figures and later armed groups according to their ideological affiliation. While Turkey and Qatar provided support to affiliates of the Muslim Brotherhood, Saudi Arabia backed other rebel groups, both secular and Salafi. This decisively contributed to the disunity of the "rebel camp". Interestingly, this also led to a regional re-alignment of Hamas, which gave more pre-eminence to the solidarity among Muslim Brotherhood affiliates than to its participation into the so-called "axis of resistance" (against Israel) led by Iran. As a result of this shift, the leadership of Hamas moved from Damascus to Doha and the aid programmes of both Qatar and Turkey to Gaza increased.

Finally, the conflict in Libya, particularly after the collapse of the transition in 2014, also reflected the confrontation between two ideologically antagonistic constellations of local and regional actors. After the 25 June elections, two centres of power emerged: Tripoli, which received the support of Qatar and Turkey, and Tobruk, backed by the Emirates and Egypt. These four countries were not the only regional players to take sides, but they were the most influential ones. This involvement translated into financial and military support for the parties to the conflict. Among the anti-Muslim Brotherhood camp, it even triggered the launch of military operations on Libyan soil. ${ }^{19}$ The involvement of all these regional powers, some of which are relative newcomers to the Maghreb and to the great power game, such as Qatar and the UAE, indicates that by 2014 Libya had become a proxy war with a strong ideological component. It is also revealing that those regional powers that are alien to this intra-Sunni ideological confrontation, such as Iran or Israel, kept a low profile in this particular conflict.

As noted above, this ideological clash lor rather this meddling and intervention in the political systems of other states) is reminiscent of the confrontation between status quo and revisionist powers half a century ago, as today we can also group states as respectively status quo and revisionist powers. However, curious changes have occurred since 2011. The once-revolutionary lor revisionist) Iran is now upholding "status quo conservative" institutions, such as territorial integrity and state sovereignty. Indeed, in Iraq, Tehran opposed the Kurdish independence referendum and from 2014 onwards decisively supported Baghdad in regaining control of its territory through the anti-ISIS campaign. In Syria, Iranians supported the regime and vehemently rejected the military support of foreign powers to the rebel camp as interference in Syrian internal affairs. In contrast, Saudi Arabia's interventionism in Yemen and the Emiratis' support to Yemeni secessionist groups, the conditions imposed on Qatar to lift the boycott or Turkey's unilateral military campaigns in Nortern Syria, can all be interpreted as signs that the once conservative/status quo camp is increasingly prone to take risks and challenge the existing order and its institutions.

\subsection{PATTERNS OF COOPERATION: LIQUID ALLIANCES AND THE MIRAGE OF REGIONALISM}

Regional organizations in the MENA region have traditionally been weak le.g. Aarts 1999, Salloukh and Brynen 2004, Harders and Legrenzi 2008, Fawcett 2013, Ferabolli 2015) and formal alliances among Middle Eastern states have never been stable. The concept of "shifting alliances"

19 In the first months of the conflict, the UAE Air Force, with Egyptian support, launched a campaign to strike governmentcontrolled targets in Tripoli. In 2017, Egypt also bombed Derna, apparently with Emirati support, in retaliation for a terrorist attack in its territory. 
is recurrent in most accounts. Stephen Walt (1987), in his well-known book on alliances in the Middle East, argued that most states face the dilemma on either balancing or bandwagoning, concluding that states tend to balance against threats rather than with the aim of power alone. In the post-2011 context, alliances are not only still shifting but they have become more volatile and inconsistent. One-off events have been changing the perception of what, or who, represents a threat and alliances have frequently become limited to single issues since 2011. These feardriven alliances, rapidly changing and constantly adapting to different landscapes, could well be conceptualized as "liquid alliances" (Soler 2017). To what extent are these liquid alliances different from what Walt and other scholars describe as "shifting alliances"? On the one hand, it is a matter of pace: the shifts occur more often and thus increase the perception that established alliances may soon dissolve. But there is a more fundamental change related to the nature and breadth of these alliances: countries may ally on one particular front and be at odds on another one. In the past, alliances shifted but were far more consistent. This may be due to two factors in particular: increased regime vulnerability and the intersection of different regional conflicts. ${ }^{20}$

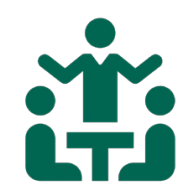

Stakeholders conference Istanbul: Current regional geopolitical competition is comparable in intensity to the Cold War, but it lacks the ideological coherence of that period.

Fear rather than shared projects or identity are the main drivers in the formation of alliances and counter-alliances in this particular context. Prior to the Arab uprisings, several authors already advanced the argument that states in the region tend to give more priority to those threats that put regime stability in jeopardy (Gause 2003, Ryan 2009). The increased sense of vulnerability in incumbent regimes since 2011 is arguably a major aspect that has infused greater fluidity into the regional order. Moreover, these regimes have observed with concern that divisions among internal factions became a key factor leading to the fall of long-serving autocrats. This means that regimes should not only fear their own people but also segments of their own power structure. Finally, mistrust was extended to international allies, at least for the countries that had mainly relied on the support of the West. One of the lessons of 2011 was that both the USA and Europe were not willing to actively engage in protecting their partners in the region. As a result, most regimes in the region seem to have reached the conclusion that they must rely on their own capacities to protect their national interests or the security of their regimes. Qatar may be an exception to this general trend, as it has increasingly relied on military support provided by Turkey.

The eruption of simultaneous and intersecting regional conflicts (Syria, Yemen and Libya) has increased the fluidity of alliance-formation. The sense of unreliability in allies has also prompted a greater assertiveness towards regional rivals. Furthermore, countries that define themselves as allies do not necessarily assign the same importance to each of the regional conflicts. Even when allies agree on who or what is the threat, they do not necessarily follow the same strategies and policies. This is well illustrated by the different positioning of Saudi Arabia, Egypt and the

20 For the concept of intersecting conflicts, see Hiltermann (2017). 
UAE, often described as allies, regarding key regional issues. For instance, different positions visà-vis Syria provoked a spat between Riyadh and Cairo in 2016. The climax of this disagreement came when Egypt aligned with Russia in a UN resolution on Aleppo and in retaliation Saudi Arabia cut oil supplies to Egypt. Abu Dhabi's low profile on Syria and even some behind-the-scenes contact with the Assad regime while other Gulf countries were adamantly campaigning for its fall is equally telling. Similar inconsistencies can be found regarding the conflict in Yemen, as Egypt's contribution of the Saudi-led Operation Decisive Storm is a very minor one, while Abu Dhabi has prioritized the fight against al Qaeda instead of combating the Houthis. Regarding Libya, the convergence and cooperation between Egypt and the Emirates is high but Saudi Arabia seems to follow a different track: instead of investing in Haftar, it is projecting influence by supporting the expansion of the Salafi Madkhali movement in Libya. Inside the "axis of resistance" divisions have also emerged. As mentioned above, when the Syrian war erupted Hamas decided to support the rebels, thus breaking its previous links with Damascus and challenging the strategy of Iran on this particular conflict.

Continued tensions among allies and open confrontation between rivals have undermined the role of formal institutions and organizations in the MENA. At first, the Arab uprisings of 2011 seemed to open a significant window of opportunity for regional cooperation and cooperative security mechanisms (Muasher 2012, Malmvig 2013: 30, Beck 2015) but it closed rather soon (Del Sarto and Soler 2018). The case of the Arab League is a telling example. This organization, often stigmatized as ineffective or irrelevant, took some bold steps regarding Libya and Syria, which reflected "a change in both its initial conception and its general behaviour" (Korany 2013: 93). Yet, from 2013 onwards power shifts and an increased sense of vulnerability fostered intraArab competition, reinforced pre-existing rivalries and even created new ones, thus pushing the Arab League to downscale its ambition. In fact, it became one among the many platforms where rivalries were staged rather than a mechanism to coordinate responses to common threats.

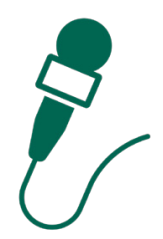

Interview with an official from an international organization in Saudi Arabia: Multilateral organizations could still play a role. And this includes the UN but also the GCC or the Arab League despite the situation they are now in. Why? Because individual states will realise that they cannot tackle many of their challenges by themselves.

The effects of these rivalries on the GCC have been even more acute. This organization was once praised for succeeding where other regionalist projects failed and not so long ago some of its members had even proposed the possibility of upgrading it into a Gulf Union. However, since 2017 the boycott of three of its six members against another one, Qatar, has represented a big blow to the credibility and viability of the organization. Although the GCC went through setbacks before, the intensity of this crisis was unprecedented. As an organization, the GCC could do little to deescalate the crisis among its members. Instead, it suffered the consequences. The hostilities among GCC states and what has been termed an "exclusionary turn in GCC politics" (Ulrichsen 2018) called into question the basic principles on which the organization was founded and prompted 
a discussion on the risks of a disintegration of the GCC or, at best, its transformation into an empty shell.

The crisis of traditional regional structures is accentuated by two additional developments: the establishment of bilateral "special relations" and the creation of multilateral coordination mechanisms that consciously exclude some regional players. The Saudi-Emirati Coordination Council in 2018 and the intensification of the Qatar-Turkey cooperation, also in the military domain, have certainly contributed to the disunity of the Gulf. Similarly, the Arab Quartet - formed by the four countries that initiated the boycott to Qatar - or the Islamic Military Counter Terrorism Coalition (IMCTC) led by Saudi Arabia are based on the idea of excluding certain regional players: Qatar in the case of the Arab Quartet, Iran and its regional allies in the case of the IMCTC (see Figure 4). The old idea of the MENA region moving towards some sort of security architecture becomes even more unlikely in these circumstances. In fact, the possible establishment of a USled Middle East Strategic Alliance, also referred to as the Arab NATO, could further strengthen this trend as it would not only exclude major regional powers such as Turkey and Iran but also Arab states such as Algeria or Iraq. This move would further fragment the region and add to the overlapping cleavages outlined above.

Figure 4 | Regionalism and beyond: Mapping regional and international organizations in the MENA

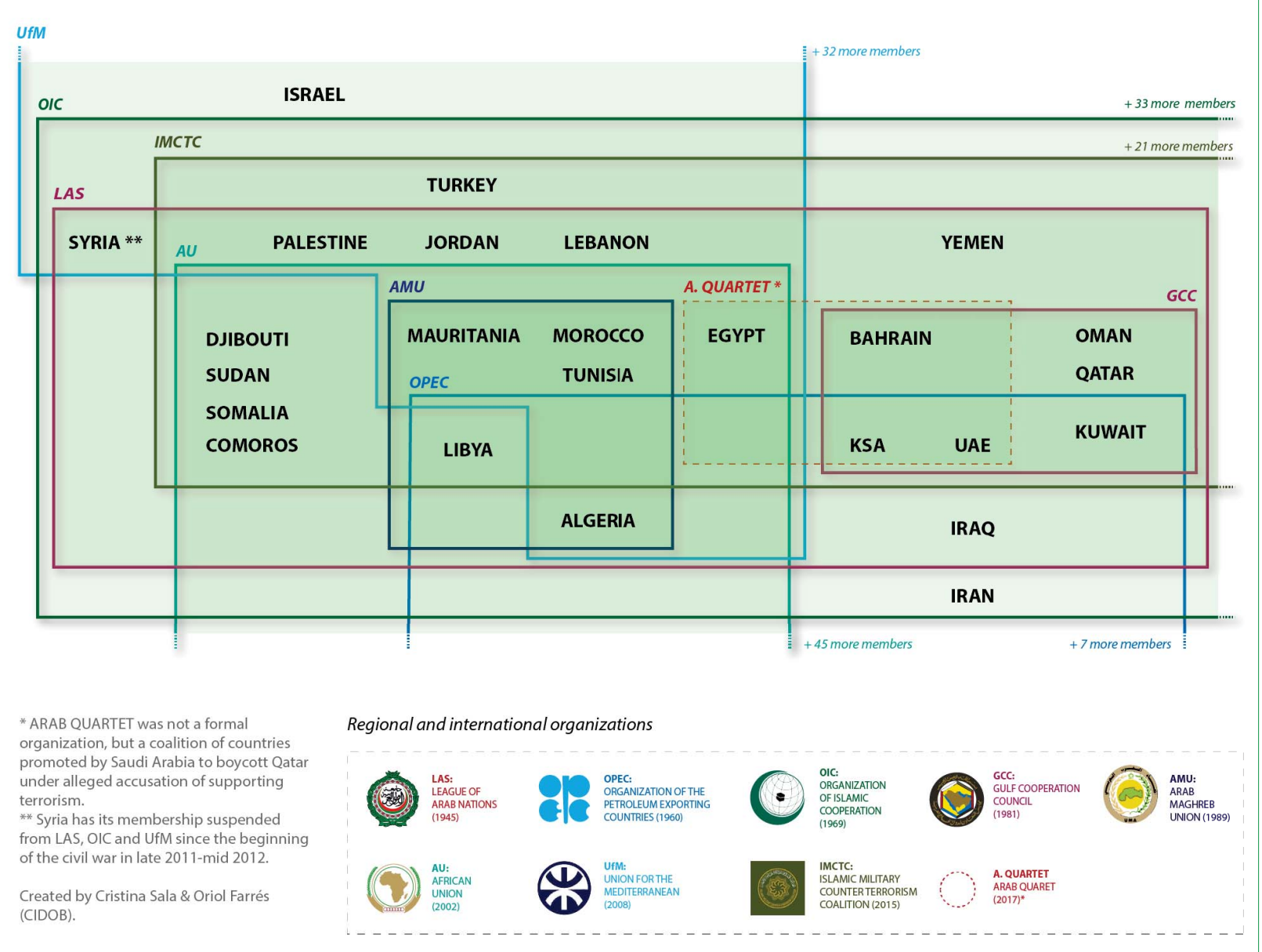




\subsection{SHIFTING CENTRES OF GRAVITY: THE GULF AND AFRICA}

The MENA region is composed of three sub-regional complexes, that is, the Maghreb, the Mashreq/ Levant and the Gulf; since 2011, we have witnessed significant changes in their relative weight and the relationship among them. The Gulf has replaced the Mashreq/Levant as the epicentre of geopolitical rivalries and the Maghreb - but also other parts of the Middle East - has been pivoting towards the African continent. The collapse of what can be referred to as the "old Arab order" facilitated the rise of the Gulf as the new powerhouse of the MENA region. The power vacuum left by the relative decline of Egypt and the neutralization of Syria and Iraq as regional powers, the proliferation of regional conflicts overshadowing the Arab-Israeli one, US policies of intervention first and disengagement later, and the abundance of resources available in several Gulf capitals increased the ambition and assertiveness of several Gulf leaders (Lynch 2018).

As argued above, Gulf countries are playing a major role in creating and sustaining the cleavages that are fracturing the region. These rivalries have manifested themselves ostensibly in the Gulf, for instance in the GCC-Iran clash amidst the deployment of the Peninsula Shield forces in Bahrain in 2011, and in the Saudi-UAE-led boycott of Qatar in 2017. The effects of these developments went beyond this sub-region, putting pressure on non-Gulf players to take sides (see Figure 5).

Figure 5 | Qatar boycott: Taking sides

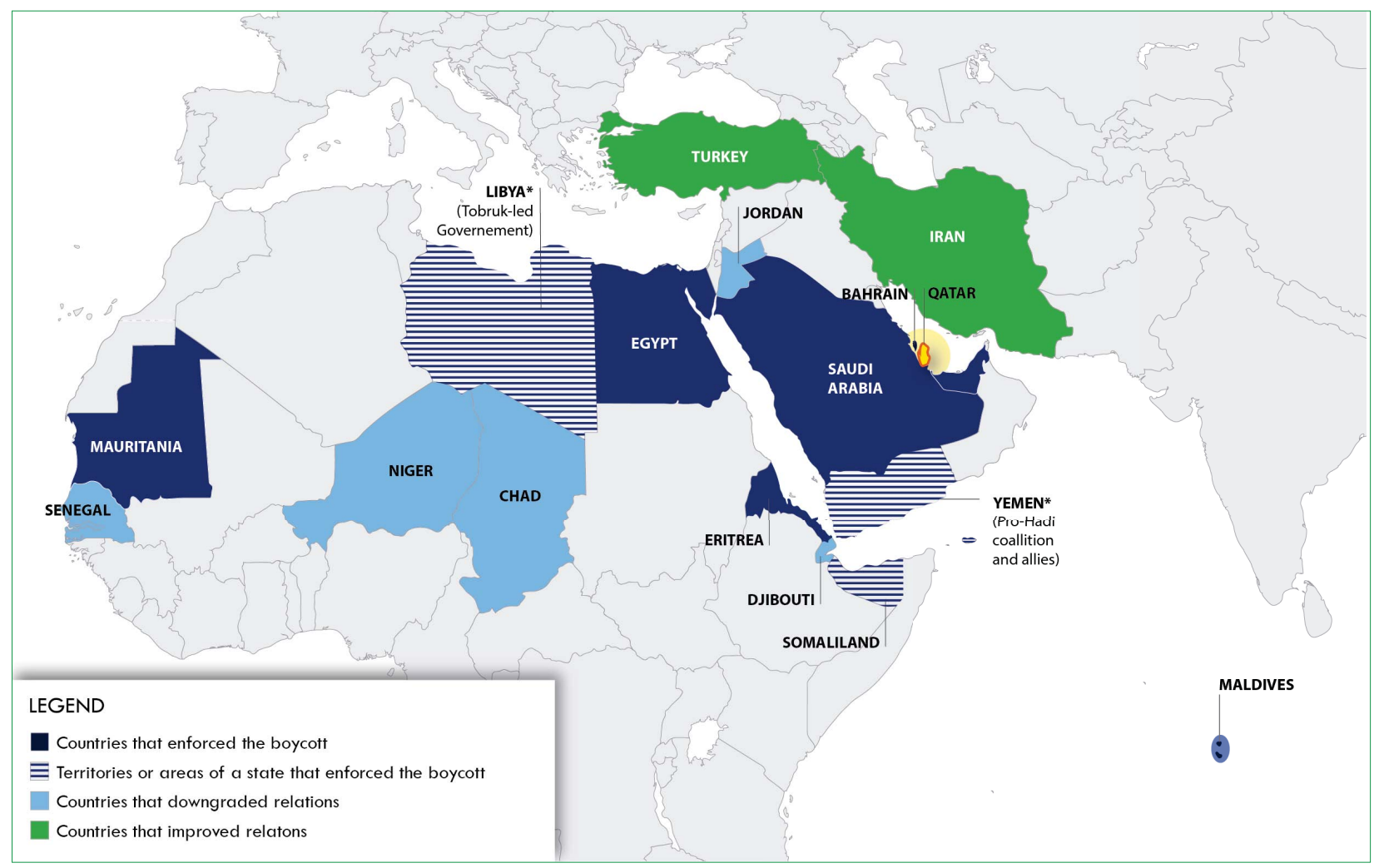

One of the novelties of the post-2011 context is that Gulf rivalries have reached North Africa, with different Gulf monarchies meddling in the political transition in Tunisia and supporting opposing 
sides in Libya (Soler 2018, Cherif 2017). Paradoxically, while the Gulf countries have thus become increasingly influential in the Maghreb, the governments and societies in this sub-region have been pivoting towards Africa. The growing connections of the Maghreb with the rest of the African continent occur in multiple domains, such as security in the Sahel, investment in West Africa, cultural and religious diplomacy, participation in African regional organizations, migration and refugees and the attempt to consolidate a Europe-Maghreb-Africa diplomatic and economic nexus. These new links indicate an increased autonomy of the Maghreb as a sub-region, or at least a willingness to achieve it. Interestingly, local stakeholders perceive the Gulf presence in the Maghreb and in Africa in general as a destabilizing factor, while the potential of a continent-tocontinent cooperation between the whole of Africa and the EU is seen as an opportunity for the Maghreb. ${ }^{21}$

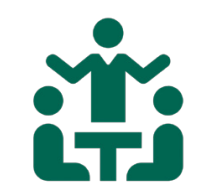

Rabat Focus Group: There is a growing interference of Middle Eastern and Gulf countries in the Maghreb. These countries also have a responsibility in the current problems in the Sahel. The Maghreb countries should agree upon a common agenda, especially when Gulf countries try to interfere in the region. To a certain extent, the Gulf may act as an external federator.

The countries of the Maghreb are not the only ones shifting their attention to the African continent. The most obvious case is Egypt, which has, however, been displaying some continuity with the pre-2011 period: Cairo has a solid diplomatic tradition of engaging in African affairs as well as vital interests in the Nile Basin. What is relatively new is Turkey's interest in Africa. While in 2009 Ankara only had twelve embassies on the continent, the number had gone up to forty-one in 2018. The Gulf countries also started to devote more attention to this region and particularly to its closest neighbours in the Horn of Africa. The mediation efforts by Saudi Arabia and the UAE in Eritrea and Ethiopia can be seen as concrete results of a strategy that aims to strengthen the links between the two shores of the Red Sea.

The shifting centres of gravity in the MENA region can be apprehended as both the result and the cause of the challenges that the regional order has been facing since 2011. In many respects, those changes are linked to broader global dynamics. For instance, and as explained in the next section, US policies have decisively contributed to increasing the Gulf's assertiveness. Similarly, the pivot to Africa is not exclusive to the countries of the MENA but is a trend that can also be traced in China's policies towards this region. 


\section{INTERNATIONAL PERMEATION AND THE DEGREE OF REGIONAL AUTONOMY}

Outside powers have historically sought to prevent Middle Eastern states from pursuing overly independent foreign policies and to keep the region from organizing autonomously, thereby hindering the rise of strong revisionist regional powers and norms (Ehteshami and Hinnebusch 1997). ${ }^{22}$ The USA and the UK are, for example, infamous for their masterminding of the military coup to overthrow the democratically elected Mossadeq in Iran. France and the UK colluded with Israel to regain the Suez Canal from Nasser, just as the Soviet Union sought to spread communist ideas, infiltrated the Palestinian Liberation Organization PLO and Kurdish movements and at one time kept over 20,000 soldiers in Egypt (Halliday 1987). Through arms transfers, military bases and billions in direct aid, Europe, the USA and the USSR have been steering Middle Eastern states their way and at various points subordinated or exacerbated regional security dynamics to their own external agendas.

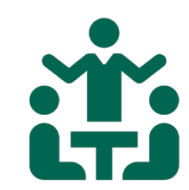

Beirut Focus Group: The Mashriq region in particular has seen over a century of non-stop interventions that have either blocked particular native forms of regional order (e.g. Arabism) or tried to establish "stable" ones favourable to the West le.g. to ensure Israeli military superiority, protect oil resources/access in the Gulf and survival of client states...). Such interventions have thus helped shape regional rivalries and balances of power; and even influenced national/domestic affairs of many states.

Yet the Cold War superpower rivalry also allowed some wiggle room for MENA governments. They were never just client states subject to external patrons' whips and wishes le.g. El-Doufani 1992, Karsh 1997). Middle Eastern states were able to gain concessions and leverage by playing off the two superpowers against each other, drawing powers into local conflicts, sometimes against these powers' immediate interests, threatening to change alliance and in some cases even doing so. Egypt's Sadat famously kicked the Soviet soldiers out of Egypt and shifted loyalty from the Soviet Union to the USA, Saudi Arabia used its oil-weapon against the West, and Israel has never been very subservient to US demands. And whereas Europe was “overlaid" by Cold War dynamics, the Middle East kept its own distinct Arab interconnectedness and indigenous security dynamics, where lines of amity and enmity would cut across, or overrule, the two superpowers' rivalry and security concerns (Buzan and Wæver 2003).

By the end of the Cold War, this regional wiggle room had narrowed considerably. With the collapse of the Soviet Union, the USA was now the only player in town. The Gulf War in 1991 and the Madrid Peace Process ushered in a new Pax Americana, where even former revisionist actors such as Syria and the PLO appeared kowtow to US demands (Ehteshami and Hinnebusch 1997). Today, 
however, the American unipolar moment is long gone. The US invasion of Iraq and its catastrophic aftermath, the US retreat from the region and Russia's willingness to fill the power vacuum in Syria, in addition to China flexing its economic muscles across the region, have created a new reality, where the USA is only one among many global powers. As a result, MENA states have greater space for manoeuvre in their foreign policies. In addition, they can draw in global powers and shape their security perceptions. Thus, the security dynamics in the MENA region show signs of a greater independence compared to the post-Cold War era.

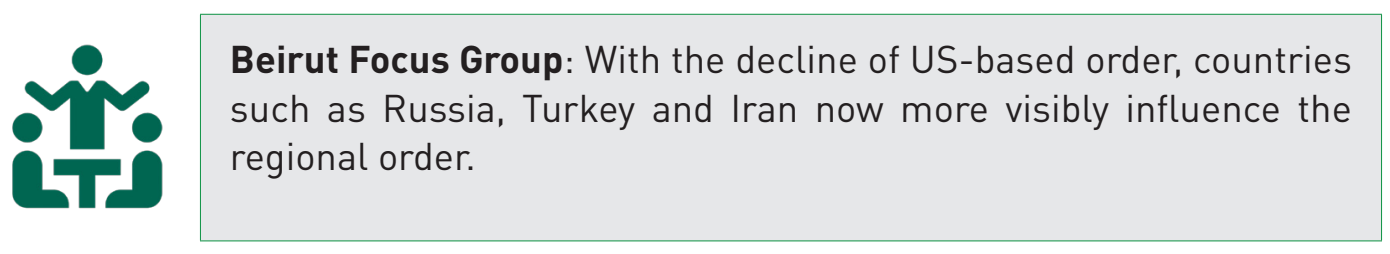

\subsection{INDEPENDENT FOREIGN POLICIES AND SPACE OF MANOEUVRE}

Turkey is a telling example of how Middle East governments can pursue foreign policies independent of, or in outright contradiction to, the wills of global powers. Despite being a NATO member and traditionally a close ally of the West, Ankara has managed to follow its own security agenda on the most divisive regional issues, such as the Syrian war, relations with Iran and the Saudi-led Qatar blockade. On the Syrian file, Turkey, a staunch supporter of the Syrian opposition, has worked for the establishment of a no-fly zone, prevented US-supported Kurdish groups (YPG/YPJ) from obtaining a contiguous territory, and only very late and reluctantly participated in the fight against the Islamic State (Al-Istrabadi 2018: 184-6). This has resulted in multiple open conflicts, threats of military confrontation with the USA in Manbij and the downing of a Russian jet in November 2015. A year later, Turkey launched its first ground operation (Euphrates Shield) in Northern Syria to remove so-called terrorist groups - including the YPG forces supported by the USA. Later, the Afrin offensive followed to "root out" the Kurdish militias, according to Erdoğan (Shaheen and Wintour 2018). The USA watched with apparent concern, but little was done.

At present, although both the USA and Russia have close ties with the Syrian Kurds, the two powers appear to have quietly accommodated Ankara's main security concerns, including accepting Turkish military presence both in the northern border regions and in Idlib. In the diplomatic arena, Turkey has similarly gained from its dual relationship with the USA and Russia. Though Turkey is part of the Western-dominated Friends of Syria Group. Ankara is at the same time playing a lead role in Russia's competing diplomatic track (the Astana and Sochi talks) and cooperates with Russia on de-escalation deals and lately on the de-militarized buffer zones in Idlib. By militarily intervening, balancing and sometimes going up against the two global powers, Turkey has probably obtained a permanent seat at any future negotiation table over Syria and the ability to decide the fate of the crucial northern regions.

Egypt, Saudi Arabia and some of the smaller Gulf states have similarly witnessed a widening room of manoeuvre, even on hard-core security and military issues. Riyadh has been given free rein in Yemen, where the kingdom is carrying out a brutal military campaign fighting the Houthis 
and seeking to put former president Mansour Hadi back in power. In 2014, Egypt and UAE twice launched secret airstrikes in Libya against Islamist forces around Tripoli without informing or seeking approval from the USA in advance. This would have been unthinkable only a few years back. And when the Lebanese Prime Minister Hariri suddenly resigned and was put under house arrest in Riyadh in 2017, the US administration again appeared surprisingly in the dark.

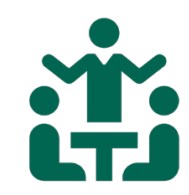

Brussels Focus Group: Overall, Russia aspires to fill gaps in an opportunistic way while at the same time benefiting from a mercantilistic strategy that gives precedence to energy and arms deals.

Across the region, Russia's return and China's rise are seen as fundamentally altering the geopolitical equilibrium. In the case of Russia, the Middle East has become a proxy domain for manoeuvring in the global political contest to win a seat among the great powers, and thus a medium for pursuing its geostrategic interests (Póti 2018: 13). Moscow's involvement in the war in Syria has transformed Russia into an international power with greater diplomatic leverage than the USA, argues Rami Khouri (2018: 6). China has also started to be perceived as an influential actor in the MENA region. As in the case of Russia, the Middle East is also instrument of power, but the goal is not only status - that would allow Beijing to portray itself as a responsible global superpower. Involvement in the region also offers a means of sustaining China's economy due to its dependence on energy supplies from the Gulf and by securing maritime routes that allow it to import raw materials and to export goods. For the time being, China has kept a low profile on highly politicized or divisive issues and has shown no appetite to become a security provider (Quero 2019). However, some decisions, such as the opening of a naval base in Djibouti, the investments in the One Belt One Road mega-infrastructure project or its willingness to participate in Syria's reconstruction efforts, indicate that China's role in this region is likely to grow.

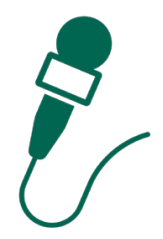

Interview with a Chinese expert: I am not sure about China's future role and influence in the region. We have never been a critical actor in the region. Now, the Belt and Road Initiative demonstrates we are interested. Yet, traditional superpowers and particularly the USA are the ones who will remain critical in shaping the region's future.

These developments have been very much welcomed by countries in the region that were at odds with the USA. Iran and Syria can now circumvent US sanction regimes and trade restrictions through China and Russia, and at times through the EU, which is developing a financial mechanism to facilitate continued trade with Iran, despite the Trump Administration's withdrawal from the Joint Comprehensive Plan of Action (the Iran deal). Even more relevant, states that continue to present themselves as US allies are very much willing to strengthen their links with Moscow and Beijing. Egypt, Saudi Arabia, Turkey and even Israel are able to play external powers off against 
each other, thereby obtaining concessions and leverage. Several US weapon systems were, for example, put on hold to Egypt, but later released after al-Sisi held meetings with Putin and after Gulf allies and Israel put pressure on the USA (Miller 2018).

\subsection{TAIL-WAGS-THE-DOG DYNAMICS: DRAWING POWERS IN AND THE INTERNALIZATION OF SECURITY PERCEPTIONS}

At times, Middle Eastern governments have even succeeded in manoeuvring global powers to do what they otherwise might not have done. Often, such tail-wags-the-dog dynamics work in rather subtle ways, as global powers internalize or uncritically take over the security perceptions of regional allies.

In June 2017, a Saudi-led alliance launched a strong blockade against Qatar, accusing it of supporting extremism and having relations with Iran. The perception of Qatar as a harbour of terrorism was seemingly shared by President Trump himself. Two weeks prior to the crisis, Trump and his family visited Riyadh, as their very first presidential trip overseas. In Riyadh, Trump secured a multibillion-dollar arms deal and attended a much-ado-about-nothing counter-terrorism summit. Afterwards, the US President tweeted: "There can no longer be funding of radical ideology. Leaders pointed to Qatar - look!" (Harwood 2018). Trump had turned Saudi security perceptions into his own. The president had, in the words of former US envoy Martin Indyk, "follow[ed] the Saudi/UAE script". Apparently Trump was unaware that Qatar hosts the largest US air base in the Middle East in Udeid, which was built by Qatar and has been used for sorties against Islamic State in Syria and Iraq (Harwood 2018). Inside the Trump Administration, Secretary of State Rex Tillerson set out to correct the course, engaged in intense regional shuttle diplomacy and quickly signed a memorandum of understanding with Qatar. However, Jared Kushner's close relationships with the Saudi Crown Prince Muhammed Bin Salman and UAE Crown Prince Mohammed bin Zayed continued to weigh heavily on Trump, while Tillerson was eventually dismissed (Woodward 2018). The two crown princes allegedly boast of holding Kushner "in the pocket" (Emmons et al. 2018) and today the Gulf crisis remains unresolved.

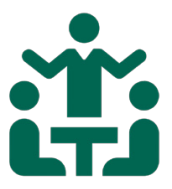

Brussels Focus Group: Middle Eastern regional players are using international powers to support their foreign policy. Both Israel and Saudi Arabia are imposing their foreign policy on neighbouring countries with the support of the USA in return for economic and strategic assistance.

The growing US preoccupation with Iran also has its own tail-wags-the-dog dynamics, as the Trump Administration has taken over Saudi and Israeli security perceptions of the country. The "adults in the room" prevented Trump from tearing up the Iran nuclear deal for a while, but Trump ended up withdrawing. Netanyahu himself took the credit for Trump leaving the deal (Maté 2018). No doubt National Security Advisor Bolton and Secretary of State Pompeo have pushed Trump further down this path, but comparing official statements on Iran from the USA, Saudi Arabia or Israel, there is little difference in language or tone. Echoing regional allies, the Trump Administration views 
Iran as the biggest threat in the region, as the largest sponsor of terrorism and accuses Tehran of seeking to dominate the whole Middle East. At the 2018 United Nations General Assembly meeting, Iran was one of the main topics in Trump's speech, in which he promised draconian new sanctions and penalties against the Europeans, the USA's closest allies, if they did not cut commercial ties with Iran. Similarly, the Iranian threat appears to have overturned Trump's impulse to withdraw from war theatres across the Middle East. Despite the fact that Trump announced numerous times that he wanted to pull out of Syria, the USA might be staying on - not in order to push the Assad regime to real transition nor to protect the Kurds, but to contain Iran, as Israel and Saudi Arabia long have worked for.

The USA is hardly the only global power subject to the ability of regional states to influence security perceptions and lure external actors into local conflicts. It was allegedly the Iranian general Soleimani who persuaded Russia to come to the rescue in Syria in 2015, when Assad and his allies were hard pressed on the battlefield. Russia has gained a large amount of international and regional leverage because of its military intervention. But Russia now sees a difficult stabilization and post-conflict situation - reminiscent of US endeavours in Iraq and Afghanistan - and an estimated 400 billion US dollars reconstruction bill that it is eager to share with Europe. Twice, and perhaps out of wishful thinking, Moscow has proclaimed that its military operation is over and that troops would be sent home soon. Moreover, as in the case of the USA, Russia's allies in Syria do not always do what Russia would like them to. Moscow has, for instance, striven to enrol the so-called auxiliary forces supported by Hezbollah and Iran into the regular Syrian army, but unsuccessfully. Similarly, Moscow initially persuaded Iran and Hezbollah forces to move farther away from Syria's southwestern border with Israel, but only for a while. As the Syrian war seems to be drawing to a close, Russian tensions with Iran and the many affiliated militias are likely to come to the fore.

The Middle East remains one of the most militarized and permeated regions in the world (see Figures 6 and 7); it is also an area that continues to be marked by outside interventions and foreign meddling. Global powers continue to have considerable clout, through transfers of billiondollar aid, loans, arms export, security guarantees and trade. But it not a one-sided patron-client relationship. Regional middle powers are able to pursue their own security agendas, lure foreign powers in and play them off to their own advantage - just as past and present attempts of external powers to impose grand security designs, from the Baghdad Pact to an "Arab NATO", have had immense difficulties in succeeding. Furthermore, as this report has shown, the nexus between the domestic and regional levels has clearly become more important after 2011 than before. Regional autonomy has increased, with mainly endogenous factors explaining change. 
Figure 6 | Arms trade in MENA: Who are the main clients of the great powers? ${ }^{23}$

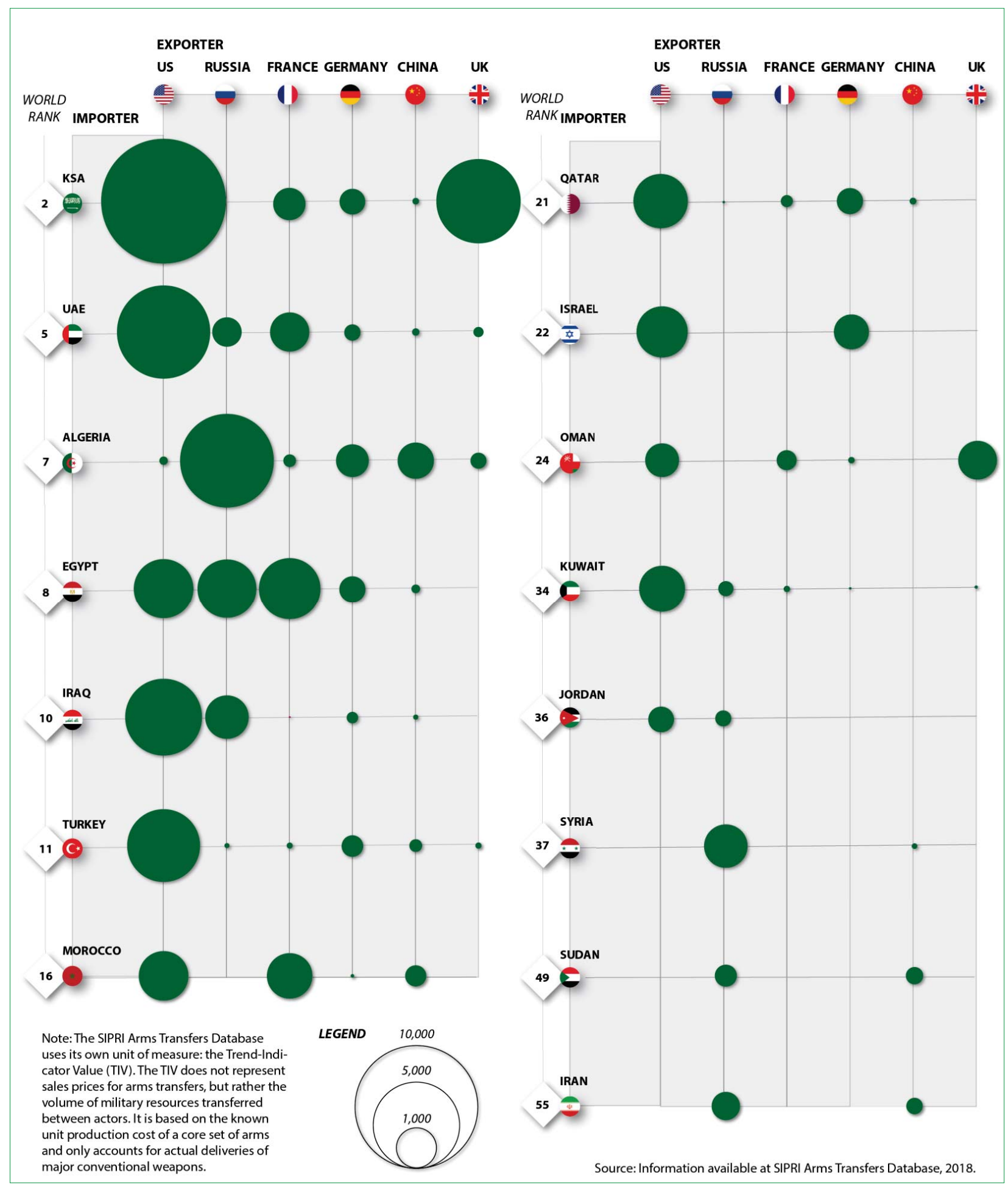

23 The MENA region is said to be one of the biggest arms markets in the world. Regional conflicts and domestic security concerns allegedly justify the need for acquiring more weaponry and new military equipment. But weapons purchases are also a way of building - or diversifying - alliances with world powers, thus positioning oneself in accordance to or against their influence over the region. An overview of arms transfers since 2010 clearly shows to which extent MENA is embedded in global competition among the great powers. 
Figure 7 | The military gap: The weight of wealth and population in military budgets ${ }^{24}$

\section{Military expenditure per capita vs. GDP per capita (2014)}

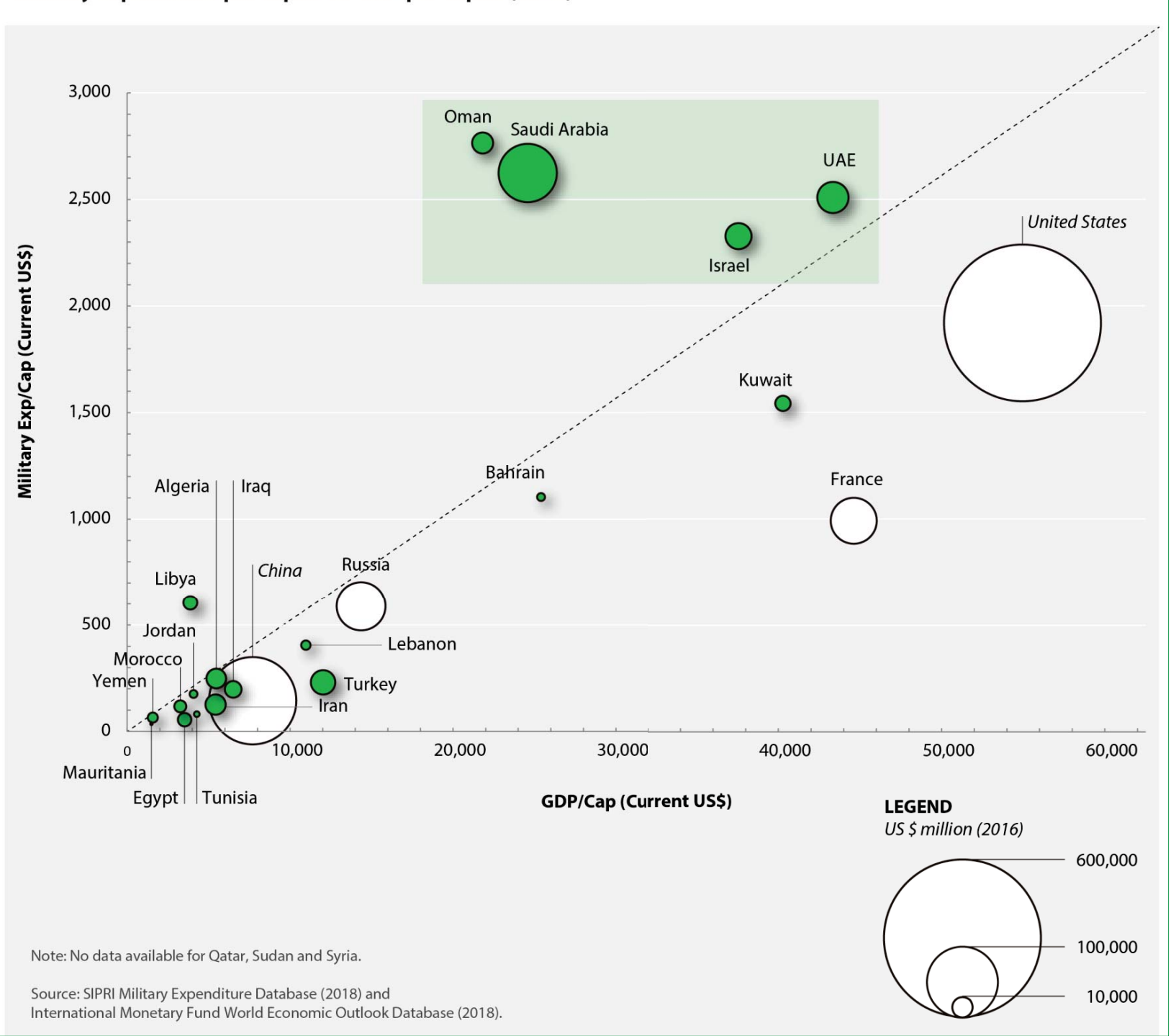

24 Comparing military expenditure with wealth and population provides an idea of whether or not military efforts are justified by demographic weight and economic capabilities. Some regional and world powers - such as Turkey, Iran, France, China, or even the USA - have huge military budgets, but do not spend that much in per capita terms and in relation to their wealth. On the contrary, a few high-income countries - namely Saudi Arabia, the UAE, Israel and Oman - spend much more than could be expected, given their much smaller populations. Looking at military expenditure in relative terms shows how countries are militarized in relation to their actual weight. 


\section{SUMMARY AND CONCLUSIONS}

A number of significant developments have characterized the MENA region since the Arab uprisings. While the state system and territorial boundaries are more resilient than widely assumed, important transformations have been taking place at the intersection of domestic and regional politics. Here, we have witnessed a weakening of a number of states in the region as the uprisings turned into armed conflicts and proxy wars unfolded in several Arab states. Although a majority of states in MENA continue to be rather strong and with robust military apparatus, wars and extreme foreign meddling have eroded state capacities, as in the cases of Syria, Libya, Yemen and to a lesser extent Egypt. Concurrently, a growing number of armed non-state actors are challenging states' monopoly on violence and territorial control. The weakening of several states in the region has had profound consequences for the shape of the regional order. The interplay between the domestic and the regional levels of politics has intensified and the so-called Arab Cold War that marked the 1950 s and 1960 s has been re-articulated. In this vein, the weakening and growing permeability of several states in the region has made it easier for domestic actors to align with external actors and to gain external support. Alongside this, regional powers have an easier time trying to undermine their regional rivals by supporting local clients in weak states, thus increasing their material and ideational power.

Equally involving the nexus between domestic and regional politics, since the Arab uprisings there has been a significant resurgence of authoritarian rule in the region, which has often taken the form of authoritarian resilience and upgrading. A more acute feeling of regime vulnerability including in relatively strong states such as Saudi Arabia, Egypt and Turkey - has further blurred the boundary between domestic and regional politics. Perceived threats to regime survival often prompt erratic and interventionist foreign policies, together with ever-shifting alliances. A notable instrument employed by Arab regimes to ensure their survival, deflect demands for change and increase their power has been the accentuation of sectarian divides. While sectarianism is far from being a new phenomenon in the region, the Arab uprisings have further widened and deepened sectarianism. Political entrepreneurs and leaders have thus manipulated fears of political exclusion and used sectarianism to discredit their domestic political opponents and regional rivals alike. Sectarian identities have become increasingly securitized, implying that these identities are portrayed as being under threat, thereby legitimizing the use of exceptional means, such as violence and repression.

A focus on predominantly autonomous developments at the regional level, which are, however, often influenced by domestic politics and international developments, reveals a number of additional significant developments since the Arab uprisings. The rivalry between Saudi Arabia and Iran is certainly a major feature of the regional system in MENA at present. However, while this antagonism pre-dates the Arab uprisings, developments after 2011 led to an intensification of the rivalry. Moreover, the 2011 uprisings and their aftermath fostered the ambitions and willingness of a number of additional regional players, such as Turkey, Qatar and the UAE, to expand their material and ideational power in the region. Other regional actors, most notably the war-torn states of Syria and Libya, and to a lesser extent Egypt, lost influence after 2011. Thus, rather than moving towards an Iranian-Saudi bipolarity, the MENA system is still marked by a multipolar order, in which the region's multipolarity is fragmented and competitive. 
Concurrently, there has been a considerable shift in the patterns of amity and enmity in the region since 2011. Three major and overlapping fault lines have become prominent: The first one separates supporters of gradually normalizing relations with Israel and their opponents. The Arab-Israeli conflict in general and the question of Palestine in particular have lost their relevance for MENA states and governments. The Israel-Gulf rapprochement, which is driven by shared hostility towards Iran, has become one of the key features of the post-2011 geopolitical landscape. The second cleavage revolves around securitized ethno-sectarian identities. Precisely because Arab norms and pan-Arab identities have lost most of their transnational appeal and mobilizing capacity, sectarian referents are filling this vacuum while state and sub-state actors willingly resort to sectarian identities in their competitive interventions and regional power games. The third fault line pits supporters of political change against defenders of the status quo. This cleavage is also linked to the question of whether the Muslim Brotherhood should be accepted as a domestic and regional political actor or whether it should be eradicated. While this ideological clash is reminiscent of the confrontation between status quo and revisionist powers half a century ago, interesting changes have occurred since 2011. For intance, once-revolutionary Iran is now upholding the status quo and conservative institutions, such as territorial integrity and state sovereignty. These overlapping cleavages go hand in hand with changing perceptions of what or who represents a threat, prompting the proliferation of liquid alliances, which are unstable, mutable and limited to single issues. The eruption of simultaneous and intersecting regional conflicts has increased the sense of unreliability of traditional allies and prompted assertive and often aggressive attitudes towards rivals and friends alike.

An additional transformation at the regional level post-2011 has been the notable shift in the centre of gravity of the MENA region. The Gulf has replaced the Mashreq/Levant as the main geopolitical centre, while the Maghreb, but also other parts of the Middle East, have been pivoting towards Africa in terms of a growing political involvement in this continent.

Finally, at the intersection between international politics and regional dynamics, signficant changes pertain to the role of the USA in the region and the emergence of new global powers. The 2003 US invasion of Iraq and its catastropic aftermath, the US retreat from the region and Russia's willingness to fill the power vaccuum in Syria (and beyond), together with China's growing economic influence in the MENA region have created a new reality in which the USA is only one among several global players. While Wahington's declining influence in the region pre-dates the Arab uprisings, the new role of Russia is linked to the aftermath of the Arab uprisings, most notably the civil war in Syria. Concurrently, traditional US allies in the region have diversified their relations with global powers and are willing to strengthen their ties with Moscow and Beijing. Many of these states, including Egypt, Saudi Arabia, Turkey and Israel, have been able to play external powers off against each other, thereby gaining concessions and leverage. MENA governments have thus increased their autonomy and space of manoeuvre. Tail-wags-the-dog dynamics have also been at work as global powers uncritically internalize the security perceptions of regional allies.

A number of conclusions can be drawn from our analysis. First, the nexus between the domestic and the regional level has clearly gained importance in explaining change in the MENA region. The state system in the Middle East still seems to be relatively stable, and international politics and shifting power dynamics at the global level obviously influence the region. However, altered state-society 
relations, together with largely autonomous regional dynamics, have had a tremendous impact on MENA's regional order. In other words, mostly endogenous factors explain the transformations that we are currently witnessing in the MENA region.

Second, many of the transformations assessed in this report point to increased conflict potential and fragmentation in the region. Increased regime insecurity and concern for their survival have promoted unpredictable and interventionist foreign policies, preventing the emergence of a peaceful regional order. Fear-mongering and sectarian securitization dynamics, once unleashed, create hard social facts that are difficult to roll back, as we have seen in Iraq and Syria. The securitization of identities may also ignite new conflicts, because this entails fear and victimhood, which can easily be exploited further. Furthermore, while the MENA region may have gained greater autonomy, the highly securitized multipolar order and the ever-shifting coalitions across different conflicts and issue-areas are causing intense uncertainty and fragmentation. Misunderstandings and distrust have become common, with mediation and de-escalation getting all the more difficult. The high level of militarization of the region is obviously not helpful here. The absence of regional "conductors", in the form of hegemonic regional powers or effective regional organizations, undermines vital negotiations and conflict resolution. Paradoxically, this is, at least in part, the sad result of previous decades of global permeations and imperial designs.

Third, the changes marking the MENA region after the Arab uprisings defy lor better, continue to defyl any black-and-white conception of regional politics. Alliances are liquid and shifting. The main cleavages defining the region today are overlapping and cut across each other, often pitting states on different sides on different issues. The rivalry between Iran and Saudi Arabia is an important feature, but it is not evidence of a new bipolarity marking the regional system. Rather, a fragmented multipolarity characterizes the region, with a number of regional powers having noticeably increased their influence and standing in MENA. Equally, sectarian antagonism is not a given fact but rather the product of social construction. And regional powers do not follow blindly the preferences of their global allies, with tail-wags-the dog dynamics being widespread. In the same vein, explanations of regional politics based on the notion of a Sunni-Shia antagonism are overly reductive, reinforcing an Orientalist understanding of the Middle East. Simplistic interpretations of the region may even lead to dangerous policy prescriptions, such as breaking up states along ethno-sectarian lines or supporting the repressive practices of autocratic governments.

Fourth, since the Arab uprisings, the disconnect between regimes and the populations in the MENA region has been growing further. Authoritarian resilience and upgrading stand in clear contrast to the aspirations of many people in the Middle East, with the socio-economic grievances that prompted people to take to the streets in 2011 not having been addressed either. Similarly significant, the securitization of ethnic and religious identities creates antagonism and fearful societies, which collide with ideas of individual rights, citizenship and inclusivity. The ever-growing gap between many MENA regimes and their populations is also visible in the persistent relevance of the Palestinian issue among Arab publics, much in contrast to their rulers. The already contested legitimacy of many rulers in the Middle East has thus weakened further.

Finally, the MENA region is still marked by the basic features that have characterized the regional order since the US invasion of Iraq in 2003. This triggered the growing antagonism between Saudi 
Arabia and Iran, the power of sectarianism, the growing influence of non-state actors, the retreat of the USA from the region, the growing fragmentation of the Arab state system and the emergence of new regional players (such as the UAE and Qatar). The region continues to be a state-centric one; the Westphalian state system in the Middle East is largely intact, at least at the systemic level. Certainly, the aftermath of the Arab uprisings prompted a number of developments, such as the growing strength of existing regional powers (mainly Saudi Arabia, Iran, Turkey and Israel), the involvement of a new global power - that is, Russia - a new configuration of status quo versus revisionist/revolutionary powers and a shift of the region's centre of gravity towards the Gulf. But it is questionable whether these trends qualify as markers of a new regional order. Similarly, the structure of the regional order, defining what constitutes a legitimate actor and setting the parameters of rightful state action, is as contested as it was before; there does not seem to have been a major change here.

Thus, while a change of the regional order does not seem to have occurred after the Arab uprisings, a number of developments in the MENA region post-2011 qualify as significant changes within the regional order. These transformations have been affecting primary institutions and issue-specific regimes that have structured relations among MENA states for decades and so formed the basis of reasonable expectations. These altered regimes and practices in the MENA region include the weakening of the domestic sovereignty of some states lentailing an ever-weakening domestic legitimacy and territorial scope of state authorityl and the growing role of non-state actors that challenge the institution/practice of state sovereignty. A reduced relevance of the Arab-Israeli conflict and the norm of Arab unity, and the prevalence of shifting and increasingly fluid alliances equally qualify as altered regimes and practices post-2011. In the long term, these amorphous transformations may well lead to the replacement of a number of key primary institutions and even to a change of the constitutional structure of the region. Referring to the epigraph by Antonio Gramsci that opened this report, we therefore conclude that in the wake of the Arab uprisings the MENA region has entered a period in which the existing order is increasingly challenged while an alternative one is still to be framed.

The authors would like to thank Morten Valbjørn and the other participants (Rasmus A. Boserup, Silvia Colombo, Jordi Quero, Aybars Görgülü, Erzsébet Rosza, Edgar Göll and Jakob Zwiers) in the MENARA workshop in Copenhagen, held in October 2018, for their valuable comments and suggestions. The report also builds on the results of focus groups organized in Brussels by Marc Otte (June 2018), in Rabat by Djallil Lounnas (July 2018), and in Beirut by Karim Makdisi (November 2018) and the on stakeholders' meetings organized by PODEM in Istanbul (November 2018) and IAI in Rome (January 2019). Thanks are also extended to Oriol Farrés, Cristina Sala, Anna Busquets and Mustafa Kaymaz for the infographics and the codification of interviews. Finally, the authors are grateful to Thomas Diez and Stephan Stetter for the opportunity to present this paper at the EISA conference in Prague in September 2018 and for their feedback on what was, at that time, a very preliminary draft. 


\section{REFERENCES}

Aarts, Paul (1999), “The Middle East: A Region without Regionalism or the End of Exceptionalism?”, in Third World Quarterly, Vol. 20, No. 5 (October), p. 911-925

Abboud, Samer N. (2016), Syria, Cambridge/Malden, Polity Press

Abdo, Geneive (2017), The New Sectarianism. The Arab Uprisings and the Rebirth of the Shi'aSunni Divide, Oxford, Oxford University Press

Ajami, Fouad (1998), The Dream Palace of the Arabs. A Generation's Odyssey, New York, Pantheon Books

Alagappa, Muthiah (2003), “The Study of International Order: An Analytical Framework”, in Muthiah Alagappa, ed., Asian Security Order. Instrumental and Normative Features, Stanford, Stanford University Press, p. 33-69

Al-Istrabadi, Feisal (2018), "Regional Constraints on the U.S. Confrontation of ISIS", in Feisal alIstrabadi and Sumit Ganguly, eds, The Future of ISIS. Regional and International Implications, Washington, Brookings Institution Press, p. 173-197, https://www.jstor.org/stable/10.7864/j. ctt1zctt19.11

Al-Rasheed, Madawi (2017), “Sectarianism as Counter-Revolution: Saudi Responses to the Arab Spring", in Nader Hashemi and Danny Postel, eds (2017), Sectarianization. Mapping the New Politics of the Middle East, London, Hurst, p. 143-158

Ayub, Fatima, ed. (2013), “The Gulf and Sectarianism”, in Gulf Analysis, November, http://www. ecfr.eu/publications/summary/the_gulf_and_sectarianism217

Aziza, Sarah (2019), “The Saudi Government's Global Campaign to Silence Its Critics”, in The New Yorker, 15 January, http://nyer.cm/BBagA00

Barnard, Anne, David M. Halbfinger and Peter Baker (2017), “Talk of a Peace Plan That Snubs Palestinians Roils Middle East", in The New York Times, 3 December, https://nyti.ms/2BIKOe3

Barnett, Michael N. (1995), “Sovereignty, Nationalism, and Regional Order in the Arab States System", in International Organization, Vol. 49, No. 3 (Summer), p. 479-510

Barnett, Michael N. (1998), Dialogues in Arab Politics. Negotiations in Regional Order, New York, Columbia University Press

Beck, Martin (2015), “The End of Regional Middle Eastern Exceptionalism? The Arab League and the Gulf Cooperation Council after the Arab Uprisings", in Democracy and Security, Vol. 11, No. 2, p. $190-207$ 
Bilgin, Pinar (2004), “Whose 'Middle East'? Geopolitical Inventions and Practices of Security”, in International Relations, Vol. 18, No. 1, p. 25-41

Bilgin, Pinar (2015), “Region, Security, Regional Security: 'Whose Middle East?' Revisited”, in Elizabeth Monier, ed., Regional Insecurity after the Arab Uprisings. Narratives of Security and Threat, Basingstoke/New York, Palgrave Macmillan, p. 19-39

Bøås, Morten and Kathleen M. Jennings (2007), “'Failed States' and 'State Failure': Threats or Opportunities?", in Globalizations, Vol. 4, No. 4, 475-485

Boserup, Rasmus Alenius and Silvia Colombo (2017), "Hybridization of Domestic Order-Making in the Contemporary MENA Region", in MENARA Methodology and Concept Papers, No. 6 (December), http://www.menaraproject.eu/?p=1093

Brown, L. Carl (1984), International Politics and the Middle East. Old Rules, Dangerous Game, Princeton, Princeton University Press

Buzan, Barry (2014), An Introduction to the English School of International Relations. The Societal Approach, Cambridge/Malden, Polity

Buzan, Barry and Ana Gonzalez-Pelaez, eds (2009), International Society and the Middle East. English School Theory at the Regional Level, Basingstoke/New York, Palgrave Macmillan

Buzan, Barry and Ole Wæver (2003), Regions and Powers. The Structure of International Security, Cambridge, Cambridge University Press

Call, Charles T. (2010), “Beyond the 'Failed State': Toward Conceptual Alternatives”, in European Journal of International Relations, Vol. 17, No. 2, p. 303-326

Cherif, Youssef (2017), “Les relations indécises de la Tunisie avec les pays du Golfe”, in Orient XXI, 17 April, https://orientxxi.info/magazine/les-relations-balbutiantes-de-la-tunisie-avec-le-golfe, 1810

Collombier, Virginie et al. (2018), "Armed Conflicts and the Erosion of the State: The Cases of Iraq, Libya, Yemen and Syria", in MENARA Working Papers, No. 22 (November), http://www. menaraproject.eu/?p=1323

Corm, Georges G. (1988), Fragmentation of the Middle East. The Last Thirty Years, London: Hutchinson

Dalay, Galip (2017), “Break-up of the Middle East: Will We See a New Regional Order?”, in Middle East Eye, 22 August, https://www.middleeasteye.net/node/65572

Darwich, May and Tamirace Fakhoury (2016), “Casting the Other as an Existential Threat: The Securitisation of Sectarianism in the International Relations of the Syria Crisis", in Global Discourse, Vol. 6, No. 4, p. 712-732 
Dawisha, Adeed (2003), Arab Nationalism in the Twentieth Century. From Triumph to Despair, Princeton, Princeton University Press

Dazi-Héni, Fatiha (2016), “Can We Speak of a New Regional Order Driven by the Gulf States after the Arab Spring?", in IEMed Mediterranean Yearbook 2016, p. 237-240, https://www.iemed. org/publicacions-en/historic-de-publicacions/anuari-de-la-mediterrania/sumaris/iemedmediterranean-yearbook-2016

Del Sarto, Raffaella A. (2017a), “Contentious Borders in the Middle East and North Africa: Context and Concepts", in International Affairs, Vol. 93, No. 4 (July), p. 767-787, https://doi.org/10.1093/ia/ iix070

Del Sarto, Raffaella A. (2017b), Israel under Siege. The Politics of Insecurity and the Rise of the Israeli Neo-Revisionist Right, Washington, Georgetown University Press

Del Sarto, Raffaella A. (2018), “Identity and Insecurity: The Rise of Ethno-Religious Politics in Israel and the Broader Middle East", paper presented at the Annual Conference of the British Society of Middle East Studies (BRISMES), London, June

Del Sarto, Raffaella A. (2019), “Insecurity, Identity Politics, and the Restructuring of the Middle East", in POMEPS Studies, No. 34, forthcoming

Del Sarto, Raffaella A. and Asli S. Okyay (2017), “After Mosul, Are Borders and State Sovereignty Still an Issue in the Middle East?", in OUPblog, 17 September, https://blog.oup.com/?p=133577

Del Sarto, Raffaella A. and Eduard Soler i Lecha (2018), “The Mirage of Regionalism in the Middle East and North Africa post-2011", in MENARA Working Papers, No. 18 (October), http://www. menaraproject.eu/?p=1296

Dodge, Toby (2014), “Can Iraq Be Saved?”, in Survival, Vol. 56, No. 5 (October-November), p. 7-20, https://doi.org/10.1080/00396338.2014.962795

Ehteshami, Anoushiravan and Raymond A. Hinnebusch (1997), Syria and Iran. Middle Powers in a Penetrated Regional System, London, Routledge

El-Doufani, Mohamed M. (1992), “Regional Revisionist Client States under Unipolarity”, in Third World Quarterly, Vol. 13, No. 2, p. 255-265

Emmons, Alex, Ryan Grim and Clayton Swisher (2018), “Saudi Crown Prince Boasted That Jared Kushner Was in His Pocket", in The Intercept, 21 March, https://interc.pt/2DKsRQK

Fawcett, Louise (2011), “Regional Leadership? Understanding Power and Transformation in the Middle East", in Nadine Godehardt and Dirk Nabers, eds, Regional Powers and Regional Orders, London/New York, Routledge, p. 155-172 
Fawcett, Louise (2013), “Alliances and Regionalism in the Middle East”, in Louise Fawcett, ed., International Relations of the Middle East, 3rd ed., Oxford, Oxford University Press, p. 185-204

Fawcett, Louise (2017), "States and Sovereignty in the Middle East: Myths and Realities", in International Affairs, Vol. 93, No. 4 (July), p. 789-807, https://doi.org/10.1093/ia/iix122

Ferabolli, Silvia (2015), Arab Regionalism. A Post-Structural Perspective, New York, Routledge

Gause, F. Gregory III (2003), "Balancing What? Threat Perception and Alliance Choice In The Gulf”, in Security Studies, Vol. 13, No. 2, p. 273-305

Gause, F. Gregory III (2014), “Beyond Sectarianism: The New Middle East Cold War”, in Brookings Doha Center Analysis Papers, No. 11 (July), http://brook.gs/2bl1yS3

Gause, F. Gregory III (2017), “Ideologies, Alignments and Underbalancing in the New Middle East Cold War", in PS: Political Science and Politics, Vol. 50, No. 3 (July), p. 672-675, https://doi. org/10.1017/S1049096517000373

Goldberg, Jeffrey (2018), “Saudi Crown Prince: Iran's Supreme Leader “Makes Hitler Look Good'”, in The Atlantic, 2 April, https://www.theatlantic.com/international/archive/2018/04/mohammedbin-salman-iran-israel/557036/

Gramsci, Antonio (1996), Prison Notebooks. Volume II, edited and translated by Joseph A. Buttigieg, New York, Columbia University Press

Haas, Mark. L. (2014), “Ideological Polarity and Balancing in Great Power Politics”, in Security Studies, Vol. 23, No. 4, p. 715-753

Haddad, Fanar (2011), Sectarianism in Iraq. Antagonistic Visions of Unity, London, Hurst

Halliday, Fred (1987), “Gorbachev and the 'Arab Syndrome': Soviet Policy in the Middle East”, in World Policy Journal, Vol. 4, No. 3 (Summer), p. 415-442

Halliday, Fred (2005), The Middle East in International Relations. Power, Politics and Ideology, Cambridge, Cambridge University Press

Harders, Cilja and Matteo Legrenzi, eds (2008), Beyond Regionalism? Regional Cooperation, Regionalism and Regionalization in the Middle East, Aldershot, Ashgate

Harwood, Anthony (2018), “GCC Crisis: What's Behind Trump's Volte-face on Qatar”, in The New Arab, 19 January, https://www.alaraby.co.uk/english/comment/2018/1/19/gcc-crisis-whatsbehind-trumps-volte-face-on-qatar 
Hashemi, Nader and Danny Postel (2017), “Introduction: The Sectarianization Thesis”, in Nader Hashemi and Danny Postel, eds (2017), Sectarianization. Mapping the New Politics of the Middle East, London, Hurst, p. 1-22

Hazbun, Waleed (2018), "Regional Powers and the Production of Insecurity in the Middle East", in MENARA Working Papers, No. 11 (September), http://www.menaraproject.eu/?p=1261

Henderson, Simon (2017), “From Bahrain to Jerusalem”, in Foreign Policy, 13 December, http:// atfp.co/2ynaZIX

Hernando de Larramendi, Miguel (2018), “Doomed Regionalism in a Redrawn Maghreb? The Changing Shape of the Rivalry between Algeria and Morocco in the Post-2011 Era", in The Journal of North African Studies, 23 March, DOI: 10.1080/13629387.2018.1454657

Heydemann, Steven (2007), “Upgrading Authoritarianism in the Arab World”, in Brookings Saban Center Analysis Papers, No. 13 (October), http://brook.gs/2bYJ76i

Hiltermann, Joost (2017), “Tackling the MENA Region's Intersecting Conflicts", in ICG Commentaries, 22 December, https://www.crisisgroup.org/node/5985

Hinnebusch, Raymond (2003), The International Politics of the Middle East, Manchester, Manchester University Press

Hinnebusch, Raymond (2014), “The Middle East Regional System”, in Raymond Hinnebusch and Anoushiravan Ehteshami, eds, The Foreign Policies of Middle East States, 2nd ed., Boulder, Lynne Rienner, p. 35-72

Hinnebusch, Raymond (2016), “The Sectarian Revolution in the Middle East”, in R/evolutions: Global Trends \& Regional Issues, Vol. 4, No. 1, p. 120-152, http://revjournal.org/hinnebusch-thesectarian-revolution-in-the-middle-east

Hudson, Michael C. (1992), “The Middle East under Pax Americana: How New, How Orderly”, in Third World Quarterly, Vol. 13, No. 2, p. 301-316

Hudson, Michael C. (1996), "To Play the Hegemon: Fifty Years of US Policy toward the Middle East", in The Middle East Journal, Vol. 50, No. 3 (Summer), p. 329-343

Human Rights Watch (2019), Egypt: Little Truth in Al-Sisi's '60 Minutes' Responses, 7 January, https://www.hrw.org/node/325806

Hurrel, Andrew (2016), “Regional Powers and the Global System from a Historical Perspective”, in Daniel Flemes, ed., Regional Leadership in the Global System: Ideas, Interests and Strategies of Regional Powers, Farnham/Burlington, Ashgate, p. 15-27 
Hüsken, Thomas (2017), “The Practice and Culture of Smuggling in the Borderland of Egypt and Libya", in International Affairs, Vol. 93, No. 4 (July), p. 897-915, https://www.chathamhouse.org/ node/30447

Jankowski, James (1997), “Arab Nationalism in 'Nasserism' and Egyptian State Policy, 1952-1958”, in James Jankowski and Israel Gershoni, eds, Rethinking Nationalism in the Arab Middle East, New York, Columbia University Press, p. 150-168

Jankowski, James and Israel Gershoni, eds (1997), Rethinking Nationalism in the Arab Middle East, New York, Columbia University Press

Kamel, Lorenzo et al. (2016), “The Past: Terminology, Concepts and Historical Junctures”, in Eduard Soler i Lecha et al., eds, "Re-Conceptualizing Orders in the MENA Region: The Analytical Framework of the MENARA Project", in MENARA Methodology and Concept Papers, No. 1 (November), p. 7-32, http://www.menaraproject.eu/?p=776

Karsh, Efraim (1997), “Cold War, Post Cold War: Does It Make a Difference for the Middle East?", in Review of International Studies, Vol. 23, No. 3 (July), p. 271-291

Katzir, Itamar (2018), “Israel's Anthem Plays in Abu Dhabi for First Time as Judoka Wins Gold”, in Haaretz, 28 October, https://www.haaretz.com/israel-news/1.6600967

Kausch, Kristina (2014), “Competitive Multipolarity in the Middle East”, in IAI Working Papers, No. 14|10 (September), https://www.iai.it/en/node/2358

Kerr, Malcolm H. (1971), The Arab Cold War. Gamal 'abd Al-Nasir and His Rivals, 1958-1970, 3rd ed., London/New York, Oxford University Press

Kerr, Malcolm H. and El Sayed Yassin, eds (1982), Rich and Poor States in the Middle East. Egypt and the New Arab Order, Boulder, Westview Press

Khouri, Rami G. (2018), “The Implications of the Syrian War for New Regional Orders in the Middle East", in MENARA Working Papers, No. 12 (September), http://www.menaraproject.eu/?p=1271

Khoury, Nabeel A. (2013), "The Arab Cold War Revisited: The Regional Impact of the Arab Uprising", in Middle East Policy, Vol. 20, No. 2 (Summer), p. 73-87

Kirkpatrick, David D. (2019), “Egypt Tried to Block Broadcast of CBS Interview with President Sisi”, in The New York Times, 4 January, https://nyti.ms/2GTx9fG

Korany, Bahgat (2013), “The Middle East since the Cold War”, in Louise Fawcett, ed., International Relations of the Middle East, 3rd ed., Oxford, Oxford University Press, p. 77-100

Lake, David A. (2009), "Regional Hierarchy: Authority and Local International Order", in Review of International Studies, Vol. 35, Special issue (February), p. 35-58 
Lake, David A. and Patrick M. Morgan, eds (1997), Regional Orders. Building Security in a New World, University Park, Pennsylvania State University Press

Legrenzi, Matteo (2015), “New Dimensions of Security and Regionalism in the Middle East,” in POMEPS, "International Relations Theory and a Changing Middle East", in POMEPS Studies, No. 16 (17 September), p. 27-31, https://pomeps.org/?p=7047

Leifer, Michael (2005), Selected Works on Southeast Asia, edited by Kin Wah Chin and Leo Suryadinata, Singapore, Institute of Southeast Asian Studies

Lounnas, Djallil and Nizar Messari (2018), “Algeria-Morocco Relations and their Impact on the Maghrebi Regional System", in MENARA Working Papers, No. 20 (October), http://www. menaraproject.eu/?p=1317

Lustick, lan S. (1997), “The Absence of Middle Eastern Great Powers: Political 'Backwardness' in Historical Perspective”, in International Organization, Vol. 51, No. 4 (Autumn), p. 653-683

Lynch, Marc (2006), "Power Ploy", in The American Prospect, 20 July, https://prospect.org/ node/145562

Lynch, Marc (2016), The New Arab Wars. Uprisings and Anarchy in the Middle East, New York, PublicAffairs

Lynch, Marc (2018), “The New Arab Order”, in Foreign Affairs, Vol. 97, No. 5 (September/October), p. $116-126$

Makdisi, Karim (2017), “Intervention and the Arab Uprisings: From Transformation to Maintenance of Regional Order", in Rasmus Alenius Boserup et al., eds, New Conflict Dynamics. Between Regional Autonomy and Intervention in the Middle East and North Africa, Copenhagen, Danish Institute for International Studies, p. 93-107, https://www.diis.dk/en/node/7186

Makdisi, Karim (2018), “Palestine and the Arab-Israeli Conflict: 100 Years of Regional Relevance and International Failure", in MENARA Working Papers, No. 27 (December), http://www. menaraproject.eu/?p=1383

Makdisi, Karim et al. (2017), “Regional Order from the Outside In: External Intervention, Regional Actors, Conflicts and Agenda in the MENA Region", in MENARA Methodology and Concept Papers, No. 5 (November), http://www.menaraproject.eu/?p=1078

Malmvig, Helle (2013), “Ambiguous Endings. Middle East Regional Security in the Wake of the Arab Uprisings and the Syrian Civil War", in DIIS Reports, No. 2013/23, https://www.diis.dk/en/ node/1755

Malmvig, Helle (2014), “Power, Identity and Securitization in the Middle East: Regional Order after the Arab Uprisings", in Mediterranean Politics, Vol. 19, No. 1 (March), p. 145-148 
Malmvig, Helle (2016a), “Coming In from the Cold: How We May Take Sectarian Identity Politics Seriously in the Middle East Without Playing to the Tunes of Regional Power Elites", in POMEPS, "The Gulf's Escalating Sectarianism", in POMEPS Briefings, No. 28 (5 January), p. 8-12, https:// pomeps.org/?p=7295

Malmvig, Helle (2016b), “Eyes Wide Shut: Power and Creative Visual Counter-Conducts in the Battle for Syria, 2011-2014", in Global Society, Vol. 30, No. 2, p. 258-278

Malmvig, Helle (2017a), "Mosaics of Power. Fragmentation of the Syrian State since 2011", in DIIS Reports, No. 2018:04 (August), https://www.diis.dk/en/node/14336

Malmvig, Helle (2017b), “Wars within Wars: Regional Actors' Involvement in the Battle for Syria”, in Rasmus Alenius Boserup et al., eds, New Conflict Dynamics. Between Regional Autonomy and Intervention in the Middle East and North Africa, Copenhagen, Danish Institute for International Studies, p. 67-78, https://www.diis.dk/en/node/7186

Malmvig, Helle (2018), “Does the Middle East Still Play to the Tunes of Global Powers?”, in Al Jazeera Centre for Studies Reports, 9 October, http://studies.aljazeera.net/en/reports/2018/10/ middle-east-play-tunes-global-powers-181009084522041.html

Malmvig, Helle (2019), “Allow Me This Time to Speak as a Shi'i: The Sectarian Taboo, Securitization and Identity Politics in Hezbollah's Legitimations of Its War in Syria", forthcoming

Malmvig, Helle, Jordi Quero and Eduard Soler i Lecha (2016), “The Contemporary Regional Order", in Eduard Soler i Lecha et al., eds, "Re-Conceptualizing Orders in the MENA Region: The Analytical Framework of the MENARA Project", in MENARA Methodology and Concept Papers, No. 1 (November), p. 33-55, http://www.menaraproject.eu/?p=776

Mann, Michael (1988), States, War, and Capitalism. Studies in Political Sociology, Oxford/New York, Blackwell

Maté, Aaron (2018), “As Netanyahu Brags of Killing Iran Deal, Where's The Outcry?”, in The Real News, 23 July 2018, https://therealnews.com/?p=178032

Matthiesen, Toby (2017), “Sectarianization as Securitization: Identity Politics and CounterRevolution in Bahrain", in Nader Hashemi and Danny Postel, eds (2017), Sectarianization. Mapping the New Politics of the Middle East, London, Hurst, p. 199-214

Miller, Andrew (2018), “Trump Blinks, and Egypt's Sisi Wins”, in Foreign Policy, 10 August, http:// bit.ly/2ntmBHf

Moore-Gilbert, Kylie (2016), “Sectarian Divide and Rule in Bahrain: A Self-Fulfilling Prophecy?”, in MEI Articles, 19 January, https://www.mei.edu/publications/sectarian-divide-and-rule-bahrainself-fulfilling-prophecy 
Muasher, Marwan (2012), “A League of Their Own”, in Foreign Policy, 11 January, https://wp.me/ p40s1y-iCb

Nasr, Vali (2007), The Shia Revival. How Conflicts within Islam Will Shape the Future, New York, W.W. Norton

Noble, Paul (2008), "From Arab System to Middle Eastern System? Regional Pressures and Constraints", in Bahgat Korany and Ali E. Hillal Dessouki, eds, The Foreign Policies of Arab States. The Challenge of Globalization, 3rd ed., Cairo, American University Press, p. 67-167

Nolte, Detlef (2010), “How to Compare Regional Powers: Analytical Concepts and Research Topics”, in Review of International Studies, Vol. 36, No. 4 (October), p. 881-901, https://www.giga-hamburg. de/sites/default/files/publications/how_to_compare.pdf

Önis, Ziya and Mustafa Kutlay (2013), “Rising Powers in a Changing Global Order: The political Economy of Turkey in the Age of BRICS", in Third World Quarterly, Vol. 34, No. 8, p. 1409-1426

Organski, A.F.K. (1958), World Politics, New York, Alfred A. Knopf

Owen, Roger (2000), State, Power and Politics in the Making of the Modern Middle East, 2nd ed., London/New York, Routledge

Phillips, Christopher (2015), “Sectarianism and Conflict in Syria”, in Third World Quarterly, Vol 36, No. 2, p. 357-376

Phillips, Christopher and Morten Valbjørn (2018), “'What Is in a Name?' The Role of (Different) Identities in the Multiple Proxy Wars in Syria", in Small Wars \& Insurgencies, Vol. 29, No. 3, p. 414433

POMEPS-Project on Middle East Political Science (2015), “International Relations Theory and a Changing Middle East", in POMEPS Studies, No. 16 (17 September), https://pomeps.org/?p=7047

Póti, László (2018), “Russian Policies towards the MENA Region”, in MENARA Working Papers, No. 9 (July), http://www.menaraproject.eu/?p=1237

Quero, Jordi (2019), “China's Impact on the Middle East and North Africa's Regional Order: Unfolding Regional Effects of Beijing's Challenge to the Global Order", forthcoming

Quero, Jordi and Andrea Dessi (2019), “Unpredictability in US Foreign Policy and the Regional Order in the Middle East: Reacting vis-à-vis a Volatile External Security-Provider", in British Journal of Middle Eastern Studies, 17 February, DOI: 10.1080/13530194.2019.1580185, https://doi.org/10.108 0/13530194.2019.1580185 
Quero, Jordi and Eduard Soler i Lecha (2017), “Regional Order and Regional Powers in the Middle East and North Africa", in Immaculada Szmolka, ed., Political Change in the Middle East and North Africa. After the Arab Spring, Edinburgh, Edinburgh University Press, p. 257-280

Reus-Smit, Christian (1997), "The Constitutional Structure of International Society and the Nature of Fundamental Institutions", in International Organization, Vol. 51, No. 4 (Autumn), p. 555-589

Rózsa, Erzsébet N. (2013), "Geo-Strategic Consequences of the Arab Spring”, in IEMED/ EuroMeSCo Papers, No. 19 (June), http://ftp.euromesco.net/index.php?option=com_ content\&view=article\&id=2013

Rubin, Lawrence P. (2014), Islam in the Balance. Ideational Threats in Arab Politics, Stanford, Stanford University Press

Ryan, Curtis R. (2009), Inter-Arab Alliances. Regime Security and Jordanian Foreign Policy, Gainesville, University Press of Florida

Ryan, Curtis R. (2015), "Regime Security and Shifting Alliances in the Middle East”, in POMEPS, "International Relations Theory and a Changing Middle East", in POMEPS Studies, No. 16 (17 September), p. 42-46, https://pomeps.org/?p=7047

Salamandra, Christa (2004), A New Old Damascus. Authenticity and Distinction in Urban Syria, Bloomington, Indiana University Press

Salamandra, Christa (2013), “Sectarianism in Syria: Anthropological Reflections”, in Middle East Critique, Vol. 22, No. 3, p. 303-306

Salem, Paul (2014), “The Middle East in 2015 and Beyond: Trends and Drivers", in MEI Policy Focus, No. 2014-5 (November), https://www.mei.edu/publications/middle-east-2015-and-beyondtrends-and-drivers

Salloukh, Bassel F. (2013), "The Arab Uprisings and the Geopolitics of the Middle East", in The International Spectator, Vol. 48, No. 2 (June), p. 32-46, http://www.iai.it/en/node/867

Salloukh, Bassel F. (2017), “Overlapping Contests and Middle East International Relations: The Return of the Weak Arab State", in Political Science and Politics, Vol. 50, No. 3 (July), p. 660-663, https://doi.org/10.1017/S1049096517000348

Salloukh, Bassel F. and Rex Brynen (2004), “Pondering Permeability: Some Introductory Explorations", in Bassel F. Salloukh and Rex Brynen, eds, Persistent Permeability? Regionalism, Localism, and Globalization in the Middle East, Farnham/Burlington, Ashgate, p. 1-14

Sayigh, Yezid (1991), "The Gulf Crisis: Why the Arab Regional Order Failed”, in International Affairs, Vol. 67, No. 3 (July), p. 487-507 
Shadid, Anthony (2011), "Turkey Predicts Alliance with Egypt as Regional Anchors", in The New York Times, 18 September, https://nyti.ms/2V7ONyw

Shaheen, Kareem and Patrick Wintour (2018), "Turkey Plans Syria 'Safe Zone' As Shelling of Kurdish Area Resumes", in The Guardian, 22 January, https://gu.com/p/8x96g

Soler i Lecha, Eduard (2017), “Liquid Alliances in the Middle East”, in Notes Internacionals CIDOB, No. 169 (March), https://www.cidob.org/en/publications/publication_series/notes_internacionals/ n1_169

Soler i Lecha, Eduard (2018), "Gulf Rivalries Reach North Africa", in IEMed Mediterranean Yearbook 2018, p. 53-57, https://www.iemed.org/observatori/arees-danalisi/arxius-adjunts/ anuari/med.2018/Gulf_Rivalries_Eduard_Soler_Medyearbook2018.pdf

Solingen, Etel (2007), “Pax Asiatica versus Bella Levantina: The Foundations of War and Peace in East Asia and the Middle East'”, in American Political Science Review, Vol. 101, No. 4, p. 757-780

Solingen, Etel (2015), “Transcending Disciplinary Divide/s”, in “International Relations Theory and a Changing Middle East", in POMEPS Studies, No. 16 (17 September), p. 52-61, https://pomeps. org/?p=7047

Stephen, Matthew D. (2002), “Rising Regional Powers and International Institutions: The Foreign Policy Orientations of India, Brazil and South Africa", in Global Society, Vol. 26, No. 3 (July), p. 289309

Tessler, Mark (2009), A History of the Israeli-Palestinian Conflict, 2nd ed., Bloomington/Indianapolis, Indiana University Press

Teti, Andrea (2007), “Bridging the Gap: IR, Middle East Studies and the Disciplinary Politics of the Area Studies Controversy", in European Journal of International Relations, Vol. 13, No. 1, p. 117145

Ulrichsen, Kristian Coates (2018), “The Exclusionary Turn in GCC Politics”, in ACW Policy Analysis, 21 August, http://arabcenterdc.org/?p=8555

Valbjørn, Morten (2003), “The Meeting of the Twain: Bridging the Gap between International Relations and Middle East Studies", in Cooperation and Conflict, Vol. 38, No. 2, p. 163-173

Valbjørn, Morten (2017), “Bringing the 'Other Islamists' Back In: Sunni and Shia Islamism(s) in a Sectarianized New Middle East”, in POMEPS, “New Analysis of Shia Politics”, in POMEPS Studies, No. 28 (December), p. 52-57, https://pomeps.org/?p=9723

Valbjørn, Morten (2018), “Studying Sectarianism while Beating Dead Horses and Searching for Third Ways", in LSE Middle East Centre Blog, 17 September, https://wp.me/p3Khxv-1Mw 
Valbjørn, Morten and André Bank (2012), “The New Arab Cold War: Rediscovering the Arab Dimension of Middle East Regional Politics", in Review of International Studies, Vol. 38, No. 1 (January), p. 3-24

Wæver, Ole (1995), “Securitization and Desecuritization”, in Ronnie D. Lipschutz, ed., On Security, New York, Columbia University Press, p. 46-86

Walt, Stephen M. (1987), The Origins of Alliances, Ithaca, Cornell University Press

Woodward, Bob (2018), Fear. Trump in the White House, New York, Simon \& Schuster

Yapp, Malcolm E. (1991), The Near East since the First World War. A History to 1995, London/New York, Longman 

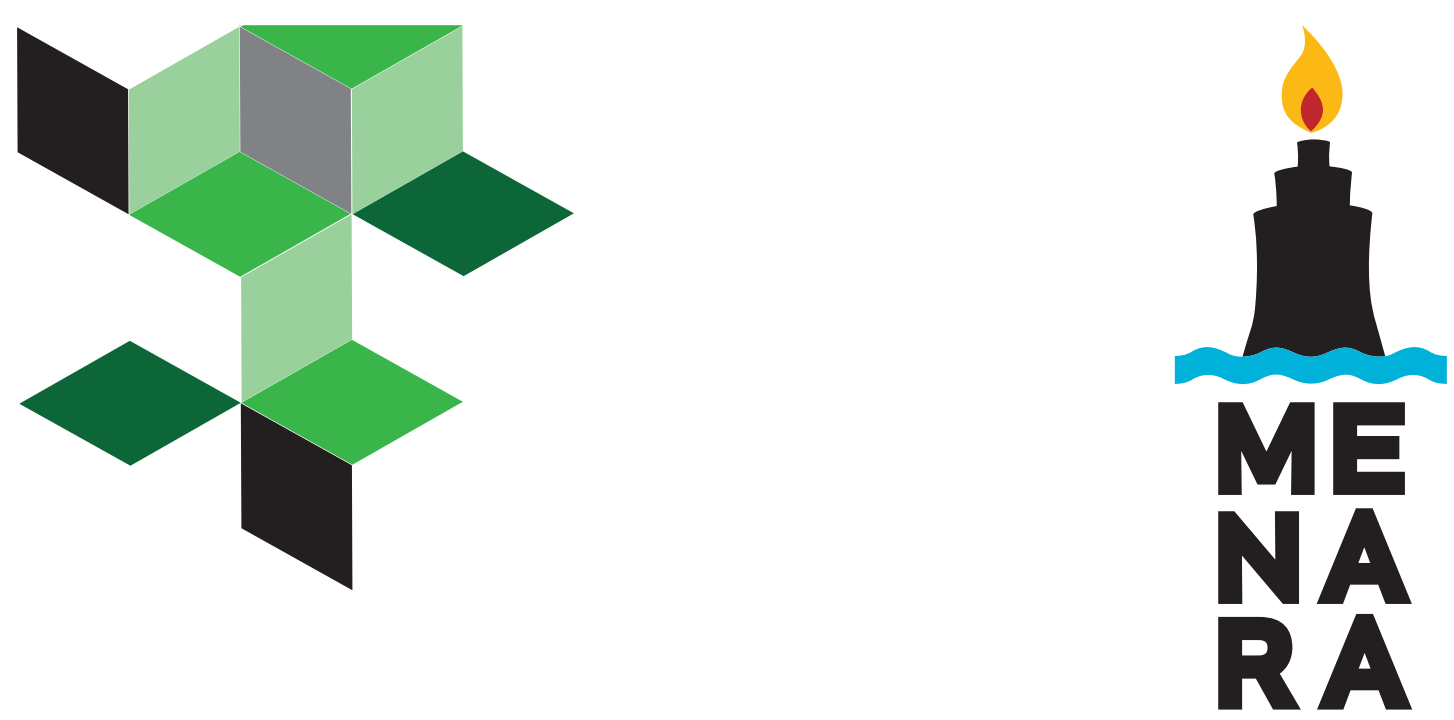

Middle East and North Africa Regional Architecture: Mapping geopolitical shifts, regional order and domestic transformations (MENARA) is a research project that aims to shed light on domestic dynamics and bottom-up perspectives in the Middle East and North Africa amid increasingly volatile and uncertain times.

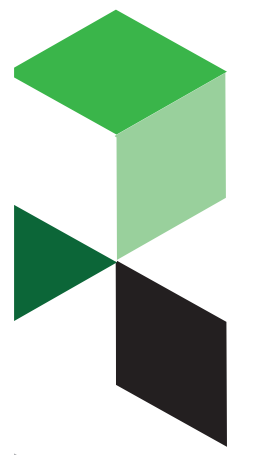

MENARA maps the driving variables and forces behind these dynamics and poses a single all-encompassing research question: Will the geopolitical future of the region be marked by either centrifugal or centripetal dynamics or a combination of both? In answering this question, the project is articulated around three levels of analysis (domestic, regional and global) and outlines future scenarios for 2025 and 2050. Its final objective is to provide EU Member States policy makers with valuable insights.

MENARA is carried out by a consortium of leading research institutions in the field of international relations, identity and religion politics, history, political sociology, demography, energy, economy, military and environmental studies.

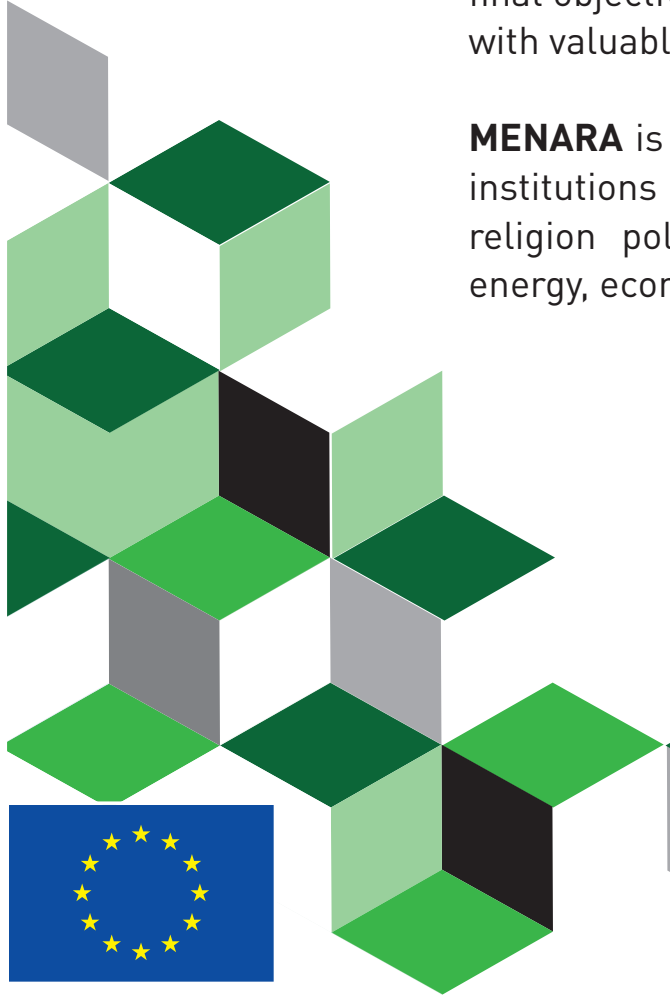

This project has received funding from the European Union's Horizon 2020 Research and Innovation programme under grant agreement No 693244. This project has been funded with support from the European Commission. This publication reflects the views only of the author, and the Commission cannot be held responsible for any use which may be made of the information contained therein.

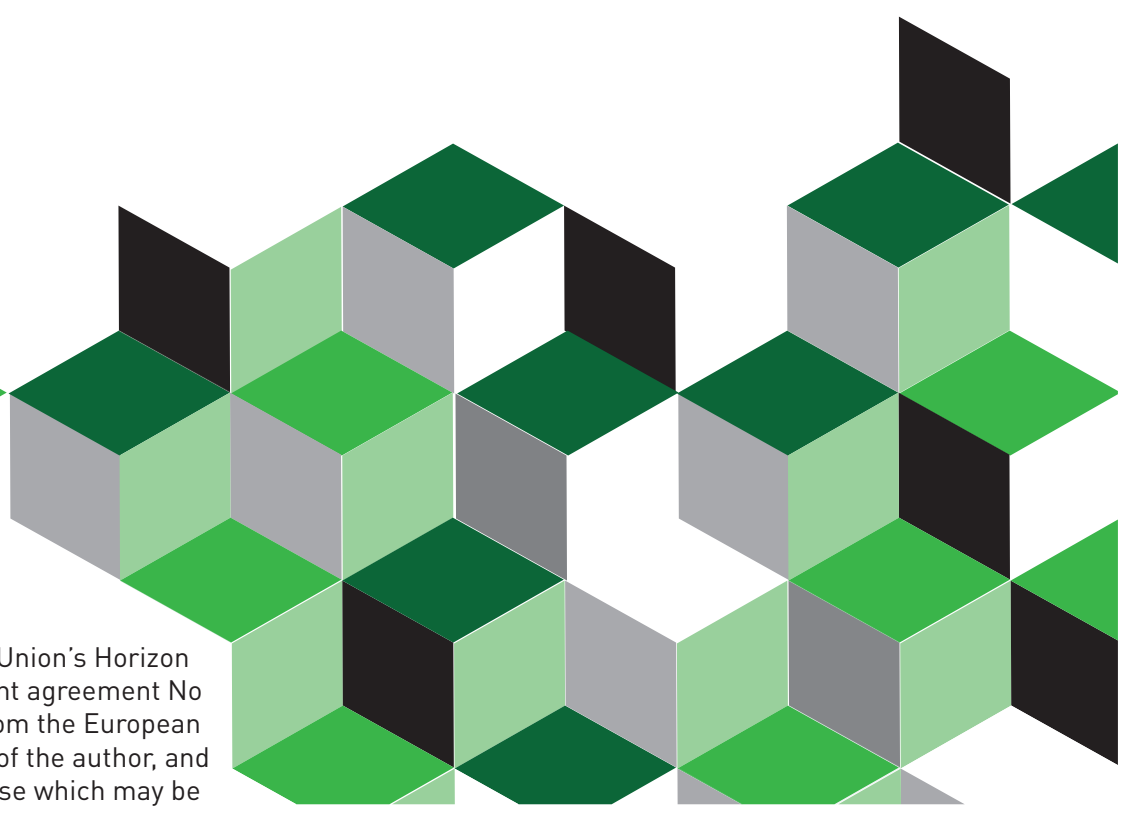

